\title{
The responses of brown macroalgae to environmental change from local to global scales: direct versus ecologically mediated effects
}

\author{
Martin Wahl1*, Markus Molis², Alistair J. Hobday³, Steve Dudgeon, Rebecca Neumann5,6, \\ Peter Steinberg ${ }^{5,6}$, Alexandra H. Campbell5,6, Ezequiel Marzinelli5,6 \& Sean Connell ${ }^{7}$
}

\author{
1 GEOMAR Helmholtz Centre for Ocean Research, Duesternbrookerweg 20, 24105 Kiel, Germany \\ 2 Section Functional Ecology, Alfred Wegener Institute, Helmholtz Zentrum für Polar- und Meeresforschung, Am \\ Handelshafen 12, 27570 Bremerhaven, Germany \\ ${ }^{3}$ CSIRO Oceans and Atmosphere Flagship, Hobart, Tasmania, 7000, Australia. \\ ${ }^{4}$ California State University, Northridge, Ca 91330-8303, USA \\ ${ }^{5}$ Centre for Marine Bio-Innovation and School of Biological, Earth and Environmental Sciences, University of \\ New South Wales, Sydney, NSW 2052, Australia \\ ${ }^{6}$ Sydney Institute of Marine Science, 19 Chowder Bay Rd, Mosman, Sydney, NSW 2088, Australia \\ 7 Southern Seas Ecology Laboratories, University of Adelaide, South Australia, Australia \\ ${ }^{*}$ Corresponding author: mwahl@geomar.de
}

With 2 figures

\begin{abstract}
In many temperate regions, brown macroalgae fulfil essential ecosystem services such as the provision of structure, the fixation of nutrients and carbon, and the production of biomass and oxygen. Their populations in many regions around the globe have declined and/ or spatially shifted in recent decades. In this review we highlight the potential global and regional drives of these changes, describe the status of regionally particularly important brown macroalgal species, and describe the capacity of interactions among abiotic and biotic factors to amplify or buffer environmental pressure on brown macroalgae. We conclude with a consideration of possible management and restoration measures.
\end{abstract}

Keywords: Ascophyllum, Ecklonia, Fucus, Laminaria, Macrocysis, disease, kelp, climate change, eutrophication, multi-factorial change, ecological modulation, phaeophyta

\section{Introduction}

Anthropogenic activities have triggered environmental changes that greatly exceed the natural (Rockstrom et al. 2009, Steffen et al. 2011, section 3). The speed of change in average environmental conditions and the increased frequency of extreme events (heat waves, hypoxia) may exceed the potential of marine organisms for tolerance or adaptation (IPCC-AR5 2014, Koehn et al. 2011). Large-scale climate changes also interact with various regional-scale stressors. The compound effects of stressors may be additive, antagonistic or synergistic, but tend to be synergistic ("unexpectedly strong") with increasing number of co-acting stressors (Crain et al. 2008, Brown et al. 2013).

Many marine populations are responding to global change (comprising climate change, shipping but also regional changes in coastal development, pollution or fish- ing; reviewed by Firth \& Hawkins 2011, see section 4) with changes in distribution, abundance, physiology and phenology (e.g. Parmesan \& Yohe 2003, Poloczanska et al. 2013). Retreating and advancing range margins, and contracting and fragmenting ranges are well documented in terrestrial systems, but are much less commonly reported from the marine realm-particularly for the ecologically important brown macroalgal species (e.g. Hawkins et al. 2009, and references therein). Ongoing and expected changes in seaweed communities are relevant since seaweed-dominated habitats are hotspots of biodiversity, represent the bases of numerous food webs and provide valuable ecosystem services (Wernberg et al. 2011a, Harley et al. 2012b).

Seaweeds may be particularly sensitive to global change because they are sessile, with limited propagule dispersal (but see Hobday 2000, Thiel \& Gutow 2004, Coleman et al. 2011) and sensitive to temperature (Breeman 1988, Eggert 2012) 
because unlike many heterotroph species they may not escape global warming by retreating into deeper (cooler but darker) waters. Seaweeds directly respond to most of the variables affected by global change (e.g. photon flux density, temperature, nutrients) in addition to being indirectly affected by shifting demographic processes such as competition, consumption, parasitism and fouling (Wahl et al. 2011, Harley et al. 2012b, Koch et al. 2013). Such sensitivities have been expertly reviewed by Harley and co-workers (2012b) while Koch and colleagues (2013) have covered the interactive impacts of warming and acidification on macroalgal physiology. Observed large scale range shifts of macroalgae represent the integrated response to multiple and interactive stress (abiotic and biotic) on all ontogenetic stages of a species (e.g.Hawkins et al. 2009, Harley et al. 2012b) although patterns may differ remarkably between taxa and regions (e.g. Lima et al. 2007, Nicastro et al. 2013, Wernberg et al. 2011a). Regional dissimilarity in response patterns may result from differences in the interactions between local and global stressors and/or be due to abiotic changes being differently amplified or buffered by shifts in competition, consumption, parasitism, epibiosis, or diseases in the various ecosystems. In particular, the ecological modulation of environmental stress is poorly understood. To help fill the gap between cause and effect (e.g. physiological sensitivity as a proximate "cause" and range shifts as an "effect") we here present several illustrative regional case studies of brown macroalgae (Fig. 1) under global change pressure. In contrast to the aforementioned reviews on macroalgae in a changing world, we strive to differentiate between global and regional scale pressures and highlight the importance of stress modulation by biotic interactions. To achieve this, we describe in detail the state and prospects for important habitat-forming brown algal species from various biogeo- graphic regions around the globe. We then summarize the suggested direct and indirect pressures in these macroalgal communities to highlight the potential for connected buffering and amplifying feed-back loops among biotic and abiotic stresses on macroalgae. We particularly emphasise the indirect effects, i.e. the mediation of abiotic stress via shifting biotic interactions. This aspect of ecological modulation of global change impacts is very poorly known even as it becomes ever more apparent that such indirect effects may outweigh the direct effects of, for instance, warming or acidification (e.g. Harley et al. 2012b). Finally, we consider the range of management options for reversing declines of impacted macroalgal populations in a changing world.

\section{Potential pressures on macroalgae}

\subsection{Abiotic pressures}

Increased human populations, particularly in coastal regions, have resulted in intensification of existing, as well as the emergence of new algal stressors, including coastal eutrophication, hypoxia (Keeling et al. 2010), invasive species (Sutherland et al. 2014), disease (Sutherland et al. 2014), and anthropogenic climate change (IPCC-AR5 2014). The climate-related change in physicochemical properties of the environment has been thoroughly reviewed and will not be covered here (e.g. IPCC 2013, Graewe et al. 2013, Doney et al. 2012). In brief, climate change results in a range of effects on the ocean including precipitation and runoff changes, and temperature and circulation changes, while the direct effects of ocean acidification are just beginning to be revealed by a range of observational and experimental studies (Doney et al. 2012). These anthropogenic stressors, many with a

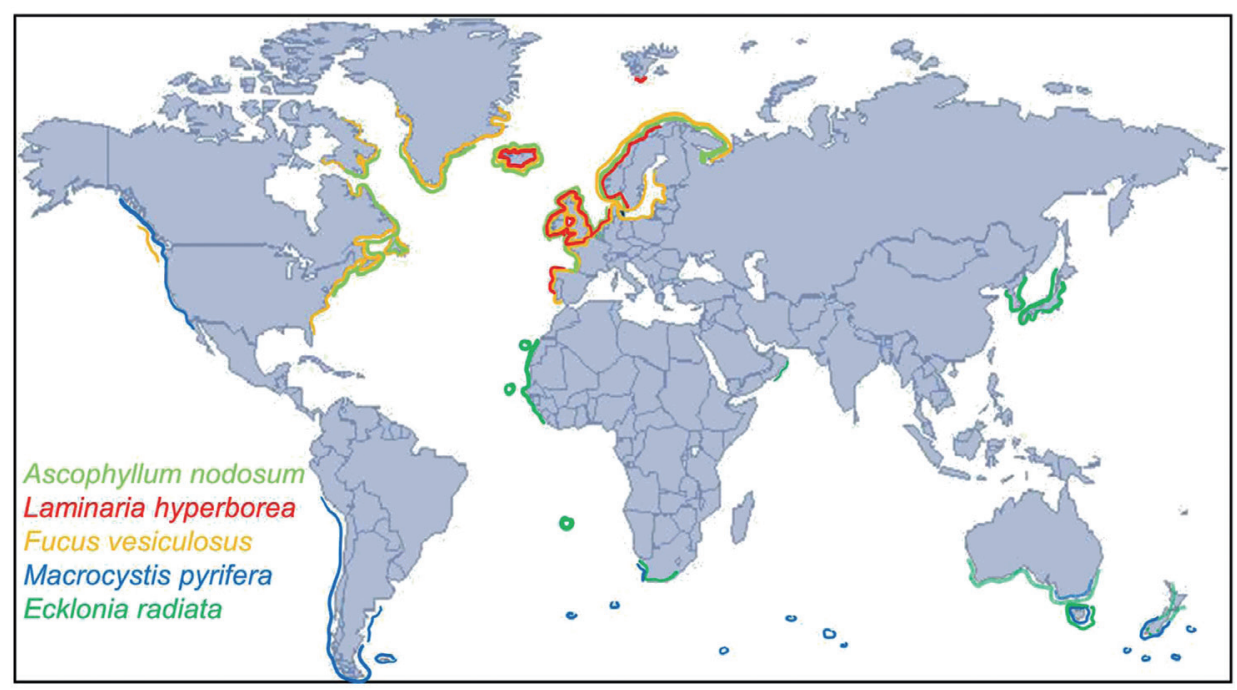

Fig. 1. Global distribution of the major brown macroalgae species treated in this review [after Steneck \& Johnson 2013, in: Bertness, M.D. et al. (2014), Marine Community Ecology and Conservation, Sinauer; GBIF and personal observation of the authors]. 
long-term trend, compound an existing natural set of oscillations at a range of time scales from short-term storm events to annual and decadal climate fluctuations (e.g. ENSO, PDO) that influence the performance of brown macroalgae. Climate variability has been an important factor in many studies on brown algae, particularly in understanding environmental stress - e.g. ENSO, temperature and nutrient availability impacting Macrocystis in California (Dayton et al. 1984). Insights from climate variability are also useful guides to the long-term change that may occur over coming decades. As an example, natural experiments with $\mathrm{CO}_{2}$ seeps are providing a window into the performance of algae in an "acidic" ocean (Hall-Spencer et al. 2008).

Model projections to 2100 and beyond strongly suggest that $\mathrm{pH}$ will decline further, ocean temperatures will rise in most places, and extremes will become more frequent (IPCC 2013). The rate of warming, but presumably also the shift in other physical variables, varies among seasons and regions (e.g. Graewe et al. 2013, IPCC 2013, BACC 2010, Hobday $\&$ Pecl 2014). Direct $\mathrm{CO}_{2}$ impacts tend to be negative for crustose coralline algae but positive for fleshy macrophytes (Koch et al. 2013), but there are also implications of ocean acidification for the grazers of brown algae (urchins), and the early life history stages of many brown algae (Gaitán-Espitia et al. 2014). Too little work has been done on the different life stages of seaweeds or with multiple stressors to allow a clear picture to emerge (e.g. Wahl et al. 2011).

Coupled with increasing areas of anoxic waters and coastal eutrophication, the outlook for coastal temperate systems is poor, with dramatic changes in macroalgal communities likely (Nellemann et al. 2008). Changes in indirect influences - e.g. nutrient supply, mixing, and grazing pressure are less certain, and model results of algal impact to date are conflicting. Overall, given the rate of change and compounding of algal stressors, we consider the probability for longterm impact is substantial. We show in subsequent sections that declines in single species are expected, with subsequent changes in community structure and composition likely, but less predictable (e.g. Wernberg et al. 2011b). For example, dramatic shifts in algal distributions attributed to coastal warming are reported for eastern Australia, where $85 \%$ of seaweed species had shifted south in the period 1990-2009 compared to $1940-1960$, while $56 \%$ on the west coast were recorded farther poleward (Wernberg et al. 2011a). Extreme events, particularly storms and marine heat waves also result in dramatic and large changes in distribution (Wernberg et al. 2012). In the following sub-sections, we detail responses to a range of regional stressors including coastal development, herbivory, competition and disease.

\subsection{Coastal development}

Human-driven environmental changes through coastal development are producing combinations of environmental conditions that may push many ecological systems outside the environmental envelope in which they evolved. Indeed, there is an increase in reporting of algal-dominated transitioning to contrasting states under altered environmental conditions (Airoldi et al. 2008). Some of the most striking of these occur in kelp forests which transition from a topographically complex, productive and diverse system to contrasting system of algae with topographic simplicity, lower diversity and productivity. These transitions from kelps to turf-dominated landscapes or algal mats occur in Norway, Sweden, Baltic, Mediterranean, Gulf of Maine, Australia and New Zealand (section 4.3).

A common feature associated with these changes is a degradation of water quality that is enriched with resources, particularly nutrients in the form of nitrogen from land-based activities (e.g. catchment management, wastewater treatment plants). Change of resource availability has long been known to play a fundamental role in regulating the productivity of individuals, species and, ultimately, communities (Harpole et al. 2011), but we are only just beginning to understand the implications of local activities that modify small-scale conditions and how they will combine with change in global conditions.

Resource enhancement is particularly problematic for the stability of algal dominated systems because they can transform normally subordinate algae to become ecological dominants. The very reason why 'kelp-turf phase-shift' tends to occur mostly on polluted coasts is because the altered water conditions favour a suite of species, which due to their physiology (i.e. fast uptake of nutrients) and life history (ability to withstand high sediment loads) are well suited for polluted environments. The increase in carbon emissions and take-up by the oceans represents carbon enrichment on a global scale and has the potential to interact with coastal development to accelerate change (Russell et al. 2009). Unlike nitrogen enrichment, which tends to be localised and occur on relatively rapid timescales of years to decades, carbon enrichment occurs on biogeographic scales and accumulates more slowly. Hence, the nature of stasis or change within the next 100 years will depend on interactions between local through global scale change in environmental conditions. For example, nitrogen enrichment on some coasts likely increases the probability of community change, but for many coasts without nutrient pollution the enrichment of carbon alone may be insufficient to drive community change. Moreover the impact of resource enrichment will vary among species, potentially leading to shifts in species dominance that reflects species-specific limitations through contrasting physiologies (Falkenberg et al. 2013). As human activities modify resource availability at different scales and places, some species may be released from these limitations while others may not be, potentially bringing considerable variability in the nature of change across the world's rocky coasts.

Further changes in the coastal environment linked to human activity such as littoral constructions providing new hard substratum, changes in current regime, suspended matter and sedimentation rates (e.g. Bulleri \& Chapman 2010), shifts in fishing pressure and disturbances linked to increasing 
tourist activities may reduce the habitat quality for macroalgae but will not be treated in detail here.

\subsection{Herbivory}

In marine habitats, the removal of biomass by grazers (interaction "4" in Fig. 2) affects plant biomass stronger than in terrestrial habitats. This is due to a higher per capita effect of marine grazers (Cyr \& Pace 1993) and a higher availability of seaweed biomass for grazers, because seaweeds often lack structural elements and, unlike terrestrial plants, lack belowground biomass (Hay 1991). Marine herbivores reduce, on average, $68 \%$ of the abundance of primary producers worldwide (Poore et al. 2012). Strongest grazing effects were reported for rocky intertidal shores, while habitats dominated by vascular plants showed the weakest effects (Poore et al. 2012). On tropical coasts 50 to $100 \%$ of seaweed production

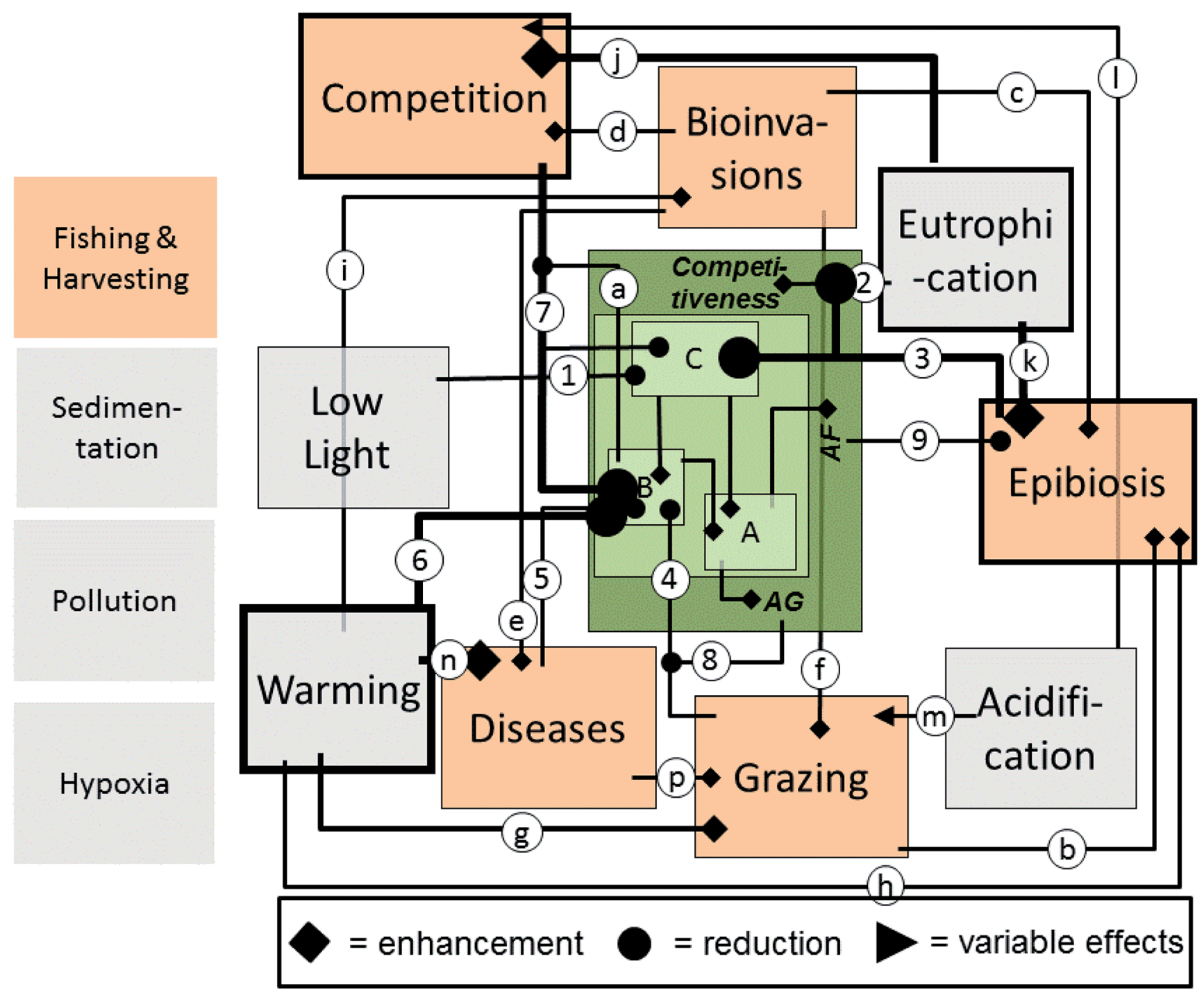

Fig. 2. Effects of some global change variables (grey) affecting the target macroalga (green) directly or indirectly via shifts in biotic interactions (orange). The conceptual scheme is incomplete, merely qualitative and mainly intended to illustrate the potential for amplifying and buffering feed-back loops. Many but not all of the effects depicted are described in the text and referred to by the effect numbers of this graph. $A=$ defense production, $B=$ growth and reproduction, $C=$ light harvesting, $A G=$ anti-grazer defense, $A F=$ anti-fouling defense. Digits = direct effect on or from the target macroalga. 1: shading lowers light harvest; 2: eutrophication may increase competitiveness; 3: shading epibionts will reduce light harvest; 4: grazing reduces biomass and, thus, net growth, reproduction and light harvesting; 5: diseases reduce fitness (growth, reproduction); 6: warming reduces fitness of brown alga at their equator-ward range margin; 7: competition reduces fitness; 8,9: defenses may limit the effects of grazing and fouling. Letters = interaction among potential stressors. a: enhanced growth increases competitiveness; b: grazing may reduce the degree of fouling; c,d,e,f: bioinvasions may increase the numbers of pathogens, grazers, epibionts and competitors; $\mathrm{g}$, h: warming tends to enhance grazing and fouling pressure, i: warming favors invasions; j,k: eutrophication favors ephemeral algal competitors (plankton, filamentous algae) and epiphytism, l: acidification favors non-calcifying over calcifying competitors, m: acidification may reduce grazing of calcifying consumers 
is often consumed, mainly by herbivorous fishes (Hay 1997), while urchin grazing may denude kelp beds at boreal to polar latitudes (e.g. Norderhaug \& Christie 2009), indicating that grazing by macro-herbivores is a major stressor for seaweeds at all latitudes. Yet, herbivores rarely consume individual seaweeds entirely. This allows seaweeds to respond to grazing and to persist by either compensating grazing-induced biomass loss with growth or by deterring grazers (" 8 " in Fig. 2; Cronin 2001). As a consequence of this seaweed persistence, meso-herbivores also use seaweeds on which they feed as a habitat and nursery ground. This spatially close association between meso-herbivores and seaweeds makes strong species interactions and co-evolution possible. The grazing activity of meso-herbivores, for instance, may indirectly affect seaweed performance and fitness because thallus damage can increase seaweed susceptibility to diseases ("p" in Fig. 2; see B5). Moreover, feeding scars in the thallus surface of tough seaweeds may facilitate consumption by grazing species that have difficulties in penetrating undamaged thallus parts (Molis et al. 2010). Epibionts may enhance or reduce the consumption of the host alga depending on the identity of the grazer (Karez et al. 2000) and the epibionts ("n" in Fig. 2; Wahl \& Hay 1995). On the other hand, grazing can be advantageous for seaweeds, because some grazers remove competing epiphytes ("o" in Fig. 2; see C4) without consumption of the underlying seaweed thallus, which receives more light and nutrients after the removal of the epiphytes (Underwood et al. 1992).

Besides biotic factors, environmental characteristics may affect seaweed accessibility and palatability for grazers. Exposure to ultraviolet radiation (UVR), for instance, induced higher levels of UVR-blocking phlorotannins in the brown seaweed Fucus vesiculosus and stimulated consumption by the isopod Idotea granulosa (Pavia et al. 1997). Furthermore, chemical anti-herbivory defences are affected in some macroalgae by irradiance and temperature (" 1 " \& "6" in Fig. 2; see 4.1). Moreover, wave exposure may shift isopod consumption among Fucus species, because isopods were able to attach better to the narrow-leafed $F$. vesiculosus than to its broad-leafed congener F. serratus (Engkvist et al. 2004). In addition, thallus toughness may be higher on waveexposed than on wave-sheltered shores, which also affects grazing impact (M Molis, unpubl. data).

Several anthropogenic factors are likely to increase rather than decrease grazing impact in a future ocean. First, cascading effects of overfishing may lead to stronger grazing pressure on seaweed assemblages, because of the reduced top-down control of (meso-)grazers. Second, ongoing depletion of stratospheric ozone will increase future irradiance of UVB radiation particularly in intertidal habitats, which may increase the consumption of seaweeds by herbivores like Idotea granulosa (Pavia et al. 1997). Third, native herbivores may provide biotic resistance to plant invasions (Parker \& Hay 2005), but the arrival of non-indigenous herbivores eliminates this ecosystem service (Parker et al.
2006), which may strongly affect the species composition of the macrophytobenthos of recipient habitats. Fourth, effects of ocean acidification may weaken the calcareous antiherbivory mechanism of certain seaweeds, but may not affect palatability of non-calcified seaweeds ("m" in Fig. 2; Gutow et al. 2014). Yet in combination with adverse effects on calcified herbivores and higher temperatures, ocean acidification may cause shifts from kelp to algal turfs ("l" in Fig. 2; Connell \& Russell 2010, see 3.2 \& 4.3). Finally, in a warmer ocean we should expect an increase in grazing impact due to higher metabolic activities (" $\mathrm{g}$ " in Fig. 2), reduced herbivore defences ("6" -> " 8 " in Fig. 2; Weinberger et al. 2011), increased herbivore populations ("g" in Fig. 2; Hernandez et al. 2010) and higher grazer diversity ("i", "f" in Fig. 2; Hawkins et al. 2009), and - enhanced by eutrophication blooms of epiphytes ("h", "k" in Fig. 2) (Saunders et al. 2010), all of which would promote a decline of large brown seaweed species.

\subsection{Competition}

Competition occurs when two organisms require the same limited resource(s) (exploitation competition) or when one organism blocks access of other organisms to resources required by the latter (interference competition) (e.g. Schiel $\&$ Foster 2006). Macroalgae need hard substratum for attachment, nutrients, $\mathrm{O}_{2}, \mathrm{CO}_{2}$ (or $\mathrm{HCO}_{3}{ }^{-}$), numerous micronutrients and trace elements for biomass build-up and light as a source of energy. Densely suspended particles (e.g. plankton, seston and sediments), but also shading neighbours as well as epibionts, interfere with a host alga's access to energy (" 3 ", "7" in Fig. 2). Dense epibiosis may also hinder the access of thallus cells of their host to gases or nutrients ("3" in Fig. 2; e.g. Wahl et al. 2011). Sediment deposits may reduce the availability of settlement substratum through inorganic deposition or organic deposition through the crash of plankton blooms (Berger et al. 2004). Sessile invertebrates compete with macroalgae for hard substratum. All primary producers, plankton, epibiotic algae, neighbouring macroalgae potentially compete for dissolved nutrients. The identity of the competitors differs among seasons, depth and region. The intensity of the competition depends on the identity and biomass of competitors, the overlap in required resources, the local availability of these resources and the capacity of the species in question to store the resources (Schiel \& Foster 2006, Wahl et al. 2011, Karez \& Chapman 1998). The capacity of many brown macroalgae to store energy and resource in a chemical form (laminaran, mannitol and the like) allows them to survive episodes of reduced resource availability (e.g. light shortage in winter, nutrient shortage in downwelling phases, etc.) (Lehvo et al. 2001, Rioux et al. 2009).

Anthropogenic changes to the marine environment have the potential of modifying actual competitive relationships (HilleRisLambers et al. 2013, Wahl et al. 2011, Harley et al. 2012a): warming may shift competitive interactions by differentially affecting the interacting species; eutrophication 
may alleviate the competition for nutrients ("2" in Fig. 2) but also enhance the biomass of competitors ("j", "k" in Fig. 2; favouring fast growing ephemeral forms to the disadvantage of perennial maroalgae, in general); acidification may reduce competition with calcifiers ("l" in Fig. 2; epibionts, competitors for hard substratum or nutrients) and - generally favour autotrophs relative to heterotrophs; bioinvasions may introduce new competitors ("d" in Fig. 2). The most important groups of competitors for macroalgae are (i) ephemeral autotrophs (plankton, filamentous macroalgae) which have the capacity to bloom by scavenging light and nutrients more efficiently in favourable periods and pass unfavourable periods in some resting form; (ii) small and fast-growing micro-epibionts like bacteria and diatoms taking up nutrients "upstream" of the macroalga and shading the host from light; (iii) other macroalgae with similar requirements, (iv) sessile invertebrates occupying hard substratum (Schiel \& Foster 2006, Rohde et al. 2008, Wahl et al. 2011, Short et al. 2014, Berger et al. 2003). Coastal constructions may enhance sedimentation stress, the availability of hard substratum and the rate of biological invasions by providing "stepping stones" (e.g. Bulleri \& Airoldi 2005). Co-existence between the different competing groups is often facilitated by strongly fluctuating environmental conditions (e.g. Namba 1984, Wilson 2011). Despite decades of field study on competition in the brown algae, most models that focus on the shifting distribution of algal species under climate change neglect how shifting competitive interactions may amplify the more direct effects of e.g. warming or acidification (but see Connell et al. 2013), and as a result considerable uncertainty remains associated with projections.

\subsection{Diseases}

Disease is a fundamental process that affects the ecology and evolution of all organisms, by altering their performance, fitness or survival but is often overlooked by ecologists relative to other processes (e.g. herbivory, competition, etc.). Diseases can have catastrophic impacts by causing widespread mass mortality (e.g. Harvell et al. 2001) or more subtle, persistent impacts, without necessarily increasing mortality (Prenter et al. 2004). Such sub-lethal impacts (e.g. reduced growth and fecundity; Burdon 1987, Myers \& Kuken 1995, Villalba et al. 2004; 5 in Fig. 2) occur because recovery from, resistance to or tolerance of disease typically incur substantial fitness or performance costs (Boots 2008, Gemmill \& Read 1998). In addition to direct impacts, disease can also indirectly affect hosts by altering their interactions with other organisms. For example, diseased hosts may be more or less susceptible to consumers ("p" in Fig. 2; Stout et al. 2006) and infection may alter an individual or species' competitive ability ("q" in Fig. 2; Park 1948, Schall 1992). Recent innovations in the field of molecular microbiology, along with improved accessibility to many environments have facilitated the inclusion of disease as a factor in ecological studies.
Our understanding of disease in natural populations of macroalgae is in its infancy. However, descriptive studies from many parts of the world suggest that diseases are common and affect diverse macroalgal species. Correa and associates have described many seaweed diseases from the coast of Chile, including a whitening phenotype in Gracilaria chilensis (Correa \& Flores 1995), 'green patch' and 'deformative' diseases in Iridaea laminarioides (Correa et al. 1994, Correa et al. 1993) and endophytic infections of Chondrus crispus (Correa \& McLachlan 1992). Endophytic infections cause thallus deformations in the kelp Saccharina latissima in the Baltic (Peters \& Schaffelke 1996) and also appear to influence its depth distribution (Schaffelke et al. 1996a). A bacterial bleaching disease affecting a chemically-defended red seaweed (Delisea pulchra) was recently described in Australia. This condition was more common when water temperatures were high ("n" in Fig. 2) and algal chemical defences low (Campbell et al. 2011, Case et al. 2011, Fernandes et al. 2012). Although this disease does not increase algal mortality, it has dramatic impacts on the fecundity of affected individuals and also increases algal susceptibility to grazing ("p" in Fig. 2; Campbell et al. 2014a). On recent continental-scale surveys of Ecklonia radiata (the dominant kelp in temperate Australia) and Phyllospora comosa (a large, canopy-forming fucoid), putative disease symptoms were widespread in natural populations of macroalgae, particularly during summer, and were correlated with changes in both algal chemistry and surface-associated microbial communities (Marzinelli, Campbell et al. in prep.). Diseases are a frequent problem in seaweed aquaculture (reviewed by Gachon et al. 2010), where bacterial (e.g. Craigie \& Correa 1996, Largo et al. 1999, Park et al. 2006), algal (e.g. Bolton et al. 2009), fungal (e.g. Amano et al. 1996) and viral (e.g. Gachon et al. 2010) pathogens impact the quality and quantity of yields of cultivated red (e.g. Kakita \& Kamishima 2006), green (e.g. Bolton et al. 2009) and brown (e.g. Park et al. 2008) seaweeds. How well this information translates for natural ecosystems remains unclear.

Recent evidence suggests that the incidence and/or severity of diseases in natural marine ecosystems are increasing (Harvell et al. 2002, Jackson 2001, Lafferty et al. 2004). The influence of environmental change on disease dynamics is likely to be complex, with direct and indirect impacts on both hosts and pathogens. Abiotic stressors can increase disease risk in macroalgae (Campbell 2011, Schaffelke et al. 1996a) and environmental change can impact upon the abundance (Pomeroy \& Wiebe 2001), 'behaviour' (e.g. enhanced virulence; Banin et al. 2002, Rosenberg \& Falkovitz 2004) or distribution of pathogens (Cook et al. 1998, Ford 1996). Many marine microbes have temperature-regulated virulence (Klinkert \& Narberhaus 2009, Konkel \& Tilly 2000), becoming more infective when waters warm up (" $n$ " in Fig. 2). Thus, it is possible that in warmer oceans, more stressed and susceptible hosts will be exposed to more abundant, widespread and virulent pathogens. Although rarely 
confirmed, diseases have been implicated in mass mortalities of macroalgae. For example, widespread losses of the canopy-forming kelp E. radiata from coastal habitats around Goat Island, near New Zealand were associated with a cold water anomaly (Cole \& Babcock 1996), overgrazing by herbivorous amphipods (Haggitt \& Babcock 2003) and an abundance of virus-like particles on necrotic kelp tissues (Easton 1995, Easton et al. 1997). Environmentally-mediated disease was suggested as a potential cause of range fragmentation of the large fucoid alga P. comosa in Australia (Coleman et al. 2008) and a bacterial pathogen caused widespread mortality of encrusting coralline algae on reefs in the tropical Pacific (Littler \& Littler 1995), but remains unidentified. Diseases of macroalgae appear to be prevalent and widespread and should therefore be included as another potential important ecological factor in seaweed ecology. The advent of novel molecular tools combined with experimental ecology renders such investigations possible now.

\section{Regional examples of stress impact}

In the following subsections we consider the current status and expected change of foundational algal species, including Ascophyllum nodosum, Laminaria hyperborea (and some other Laminaria species), Fucus vesiculosus, Macrocystis pyrifera and Ecklonia radiata. These large, perennial, canopy-forming macroalgae represent three-dimensional habitats harbouring numerous species of epibionts, sub-canopy flora and associated motile fauna, including juvenile fish (e.g.Thompson et al. 1996, Kersen et al. 2011, Ronnback et al. 2007). They contribute substantially to water quality by the fixation of nutrients and carbon, by the provision of oxygen, and by buffering environmental stress (e.g. acidification). Their ecological importance and their contribution to ecosystem functioning are increasingly recognized, as is the threat of their potential declines (e.g. Wernberg et al. 2011a, Harley et al. 2012b).

\subsection{The bladderwrack Fucus vesiculosus in the Baltic Sea}

During the past four decades, the distributional area of one of the major macrophyte species of the Baltic Sea, Fucus vesiculosus, has shrunk by over $95 \%$ (e.g. Berger et al. 2004, Torn et al. 2006 and references therein). This reduction mainly reflects a massive shoaling of the macroalgae. The trend has slightly reversed in the rocky shores of W-Sweden (Nilsson et al. 2004) but apparently not in the rest of the Baltic Sea (Torn et al. 2006). F. vesiculosus is the only macroalga providing the abovementioned ecosystem services in almost the entire Baltic Sea including much of the low-salinity regions of the eastern and northern regions. The observed decrease is, thus, alarming.

Earlier research suggested eutrophication (enhancing epibiosis) was the main driver of the decline of $F$. vesiculosus ("k" in Fig. 2; Vogt \& Schramm 1991) however, recent evidence suggests it is rather a multifactorial phenomenon (Wahl et al. 2011 and references therein): in the Western Baltic, Fucus is presently found between 0 and $2 \mathrm{~m}$ depth (Wahl et al., own obs.). Eutrophication enhances grazing (Hemmi et al. 2005) and leads to denser plankton in spring and summer (BACC 2010) that, through shading, limits the growth of Fucus below 4-5 m, but enables it above 4m (Rohde et al. 2008). However, between 2 and $4 \mathrm{~m}$, reduced irradiation ("1" in Fig. 2) plus increasingly warm water temperatures ("6" in Fig. 2) impact the capacity of the algae to produce chemical antifouling and antifeeding defenses (Weinberger et al. 2011). At the same time, circumstantial evidence suggests that fouling and feeding pressure have increased in the last decades (e.g. Korpinen et al. 2007): warming enhances microbial fouling ("h" in Fig. 2; Wahl et al. 2010), warming plus eutrophication enhance fouling by filamentous algae ("h", "k" in Fig. 2; Berger et al. 2004, Korpinen et al. 2007) and reduce recruitment of $F$. vesiculosus (Berger et al. 2004), and warming increases both the number and the per capita consumption of mesograzers ("g" in Fig. 2; Leidenberger et al. 2012, own unpubl. data) which, in their turn, are less and less controlled by fishes due to overfishing. Coastal constructions increase local sedimentation rates, which leads to suffocation of algal recruits (Berger et al. 2003). One invasive macroalga, Gracilaria vermiculophylla is a direct competitor of F. vesiculosus ("d" in Fig. 2) and indirectly impacts Fucus by favouring its consumers (isopods) (Weinberger et al. 2008): isopods hide in Gracilaria during daytime from their fish predators, but preferentially feed on nearby Fucus (and its epibionts) at night rather than on welldefended Gracilaria. Whether new pathogens or parasites impact Fucus additionally, or whether native pathogens or parasites are more virulent due to changing environmental conditions or a weakening of the macroalga's defenses is not known. The roles of these multiple stressors, their interactions and the existence of several feedback loops have been demonstrated for the Western Baltic (see references above). How this complex stress regime shifts along the alga's distributional range remains to be investigated.

\subsection{Kelp Laminaria spp. in the Northern Atlantic}

The genus Laminaria comprises more than 30 species, mainly distributed along the cold-temperate and polar coasts of both hemispheres, where Laminaria-standing crops reach $47 \mathrm{~kg}$ biomass $\mathrm{m}^{-2}$ (Bartsch et al. 2008). Laminaria species are economically (e.g. as source for alginates) and ecologically (e.g. as bio-engineers) important kelps. A single Laminaria hyperborea specimen, for instance, can provide a habitat for $>10,000$ individual mobile macroscopic invertebrates (Christie et al. 2003). For the last two decades, a growing number of studies report on changes in demographic parameters of Laminaria populations, presumably due to changes in the abiotic and biotic environment (Bartsch et al. 2008). Furthermore, a decline in the density of different Laminaria 
populations along European coasts has been observed, e.g. for L. digitata in Brittany and UK (Raybaud et al. 2013). The warming of the oceans is seen as one, perhaps the most important, cause of these changes in the biogeographic distribution of several Laminaria species, because temperature strongly controls their performance, survivorship, reproduction, and recruitment (Müller et al. 2009, Harley et al. 2012a, Bartsch et al. 2013). The growth range of cold-temperate Laminaria species, for instance, is between 0 and $20^{\circ} \mathrm{C}$ and continuous exposure to higher temperatures for about one month or longer will kill Laminaria species (Bartsch et al. 2008). Consequently, the distribution range of the cold-temperate Laminaria species is predicted (Raybaud et al. 2013, Müller et al. 2009) to shift northward, with empirical support of $L$. hyperborea arrival on the southern coasts of Svalbard (Müller et al. 2009), because growth and reproduction will improve under the milder winter conditions at higher latitude and deteriorate during hotter summer months at lower latitude. Besides temperature, ultraviolet radiation (UVR) is also known to affect the population structure of Laminaria species. Wiencke et al. (2006), for instance, showed detrimental UVR effects on germination rate in Laminaria species. Current depletion levels of stratospheric ozone suggest that Laminaria species dwelling from polar to temperate regions could be affected and that the detrimental UVR effects on zoospore structure and physiology, germination success, and growth may be intensified in a warmer ocean (Steinhoff et al. 2008, Müller et al. 2008). According to the IPCC (2014), the intensity of storms and ultimately wave exposure will increase, in particular in the Arctic. Consequently, older, larger, and more rigid specimens should be more frequently dislodged, which may alter vertical distribution patterns of Laminaria species that show different susceptibility to wave action, such as L. hyperborea with a stiff compared with L. digitata with a flexible stipe.

The arrival of non-indigenous species represents another source of environmental stress for Laminaria species. The number of released spores by $L$. longicruris from the NW Atlantic, for instance, was reduced nearly 100 -fold in kelps that were completely covered by the non-indigenous bryozoan Membranipora membranacea ("c" in Fig. 2; Saier \& Chapman 2004). In addition, the calcareous, sheet-like bryozoan colonies increased the brittleness in the thallus of several Laminaria species, stimulating wave-induced defoliation (e.g. Krumhansl et al. 2011). Grazing by e.g. the snail Lacuna vincta, can also promote Laminaria canopy loss, because feeding scars and grazing-induced perforations function as predetermined breaking points (Krumhansl et al. 2011). By concentrating grazing damage on non-encrusted areas of blades, L. vincta may act synergistically with $M$. membranacea to increase the likelihood of blade breakage and canopy loss (O'Brien et al. 2013). Infestation by endophytes may also exert a stress on Laminaria species. In the Baltic Sea, for instance, survival of shallow-water
Saccharina latissima was strongly reduced, apparently because endophyte (Streblonema aecidioides)-induced host deformations were stronger in specimens living at shallow than at greater depth (Schaffelke et al. 1996b).

In a future ocean, we expect Laminaria species to shift poleward and to deeper depth, with potentially strong regional effects on the diversity and structure of benthic communities.

\subsection{Ecklonia radiata in southern Australia}

Canopies of macroalgae represent southern Australia's predominant habitat along its rocky coast, with Ecklonia radiata being the most common kelp (Connell \& Irving 2008). At the centre of this distribution, however, canopies have undergone wholesale loss within several locations of intense coastal development. Here, the human population has increased tenfold over the last 30 years with exponential increases in the discharge of sewage and storm water that has increased coastal nutrient and sediment loads (Connell et al. 2008). This liberation of resources in the form of nutrients has enabled weedy species (i.e. turf-forming or matforming algae; Connell et al. 2014) to expand and displace perennial species of canopy-forming algae (" $\mathrm{j}$ ” in Fig. 2; Connell \& Russell 2010). This switch by low-lying mats from competitive subordinates to competitive dominants occurs in locations where quality has been degraded by terrestrially derived nitrogen, most notably catchments where urbanisation has been zoned and rapid residential development ensued (Gorman et al. 2009). The precise mechanism of kelp loss probably occurs via the ability of mats to trap sediment into their structure and prevent the successful attachment of spores of kelp and their subsequent recruitment back onto rock. The relative abundance of different types of algae often reflects resource limitations, but many of these constraints are undergoing large, rapid shifts. These new environmental conditions appear to favour species with fast rates of colonization, growth and short generation times that can competitively displace lower growing and longer-living space-holders when resource availability is increased (Gorman \& Connell 2009). The most notable of these are turf-forming or mat-forming algae (Connell et al. 2014). These algae are characteristically small, with high surface-area-to-volume ratios and high demand for resources relative to canopy-forming algae. Physiologically, they require substantial resources to enable their normally ephemeral status to become competitively superior to perennial species that characterize canopies. Mats are normally ephemeral as their covers fluctuate rapidly in response to the availability of resources for growth. An emerging issue, therefore, is the uptake of increasing carbon emissions by the oceans to increase the availability of carbon; resource enrichment at a global scale that is observable in accelerated mat growth across tropical and temperate coasts (Connell et al. 2013). Co-limitations between nitrogen and carbon are relieved by enrichment to enable mat expansion to increase 
at double the current rate (Falkenberg et al. 2013). Within the next 100 years, the levels of nutrient and carbon enrichment may combine in synergistic ways that accelerate the expansion of mat-forming algae at a pace that far exceeds that observed over the last 30 years (Russell et al. 2009). Unlike nitrogen enrichment, which tends to be localised and occur on relatively rapid timescales of years to decades, carbon enrichment occurs on biogeographic scales and accumulates more slowly. Whilst nitrogen and carbon provide direct benefits for kelp, their indirect effects on kelp, via turf expansion, exceeds any positive effect.

\subsection{The giant kelp Macrocystis}

Giant kelp, Macrocystis, forms an iconic "kelp forest" habitat with a dense surface canopy along coastal regions of the eastern Pacific Ocean from Baja California to southeast Alaska; the southern hemisphere coastlines of South America, South Africa, New Zealand, and Australia; and around many sub-Antarctic islands (Graham et al. 2007b, Fig. 1). This widespread distribution and diversity of growth forms led to several species being recognized, although recent consensus based on genetic evidence is that there is a single, morphologically plastic, species, M. pyrifera (Coyer et al. 2001; Graham et al. 2007a). Macrocystis forests support a rich diversity of species, including commercially valuable abalone, rock lobster, and many species of finfish. In some regions, Macrocystis is also commercially harvested for alginates, which are used in a range of food products.

Ecological studies of Macrocystis forests, particularly those based on long-term natural and designed experiments have made a strong contribution to several ecological "principles" involving stress. Foremost of these is the discovery of marine trophic cascades, with the kelp-urchin-otter interactions considered a classic in ecology (Estes et al. 1998, Foster \& Schiel 1988). Predator-prey experiments, based in Macrocystis habitats, revealed the importance of urchin grazing ("4" in Fig. 2; Dean et al. 1984, Harrold \& Reed 1985), while clearing experiments revealed responses of the understory algal species and showed competition for resources between algal species ("7" in Fig. 2; e.g. Graham et al. 2007b). Long-term monitoring has also been important in kelp forest ecology, with variation in distribution and abundance in response to stressors observed on many time scales. Californian studies first showed the importance of nutrient supply ("j", "k" in Fig. 2), which varied with ENSO events and sewage spills (Tegner et al. 1995). Extreme events play an important role in kelp forest dynamics, with storms capable of eliminating large forests (Dayton et al. 1992). Opportunistic study following storms showed successional stages of recovery that revealed complex dynamics and interactions (e.g. Tegner et al. 1997).

In Tasmania, reanalysis of aerial survey photographs and mapping from the 1940's have revealed a long-term Macrocystis decline attributed in part to climate change and coastal warming (Johnson et al. 2011, Edyvane 2003).
With less than $10 \%$ of former kelp forest habitat remaining in south-east Australia, in 2012 Macrocystis was the first Australian marine community to be listed as endangered (EPBC-Act 1999). Long-term change in Macrocystis distribution has also been linked to increased sedimentation associated with coastal development and dredging. In recent times, grazing by a range-shifting sea urchin Centrostephanus has led to extensive barrens and placed additional pressure on kelp forests and their associated species in eastern Tasmania (Ling et al. 2009, Ling 2008). Loss of predators of grazing urchins in kelp forest has been suggested to make these systems less stable and vulnerable to climate change (Steneck et al. 2002, Johnson et al. 2011). In California there is evidence that an oceanic regime shift has resulted in climate now becoming more of a forcing factor (Parnell et al. 2010). Harvesting of Macrocystis in South America has caused declines in the past (Vasquez \& Vega 1999), which led to attempts to culture plants for aquaculture feeds. Unpredictably, Macrocystis populations in northern Chile began to decrease after the 1999 La Niña (Vega et al. 2005). The direct cause remains unknown but may be linked to Macrocystis recruitment failure (Graham et al. 2007b). Early Macrocystis life history stages may be vulnerable to a different set of stressors than mature plants - for example, Gaitán-Espitia et al. (2014) showed that elevated temperature and $\mathrm{pCO}_{2}$ decreased germination rates and increased spore mortality. Overall, Macrocystis is vulnerable to a wide range of local stressors associated with human activities throughout its range, and to a growing set of stressors associated with global warming.

\subsection{Knotted wrack Ascophyllum nodosum in the Northern Atlantic}

The genus Ascophyllum consists of a single species, A. nodosum, confined to the North Atlantic Ocean. It is widely distributed, and the most abundant species (in biomass) on North Atlantic rocky shores. Standing crops typically range from 20 to $28.9 \mathrm{~kg}$ fresh $\mathrm{wt} \cdot \mathrm{m}^{-2}$ (Vadas et al. 2004). Annual productivity has been estimated up to $894 \mathrm{~g}$ $\mathrm{C} \cdot \mathrm{m}^{-2} \cdot \mathrm{yr}^{-1}$ with $50-60 \%$ percent of standing biomass lost to detrital pools through ice scour and rafting, suggesting turnover every 2 years in disturbed locations (Mathieson et al. 1982, Cousens 1984, Vadas et al. 2004). Ascophyllum is an important economic resource. Harvesting has increased, peaking at 37,000 tonnes in 2007 (Ugarte et al. 2009) in Atlantic Canada alone, for products ranging from fertilizer, cosmetics and, nutritional supplements to packing material to ship seafood. It is an open question whether current harvesting practices (cutting $\sim 15-30 \mathrm{~cm}$ above holdfast) will sustain populations that fluctuate in response to climate change.

A. nodosum is the foundation species in North Atlantic sheltered rocky shore ecosystems. Its detrital biomass provides a large subsidy for secondary consumers/decomposers, whereas consumption by herbivores is a relatively small fraction of production. On both sides of the Atlantic, 
consumer effects are variable, often weak, with the greatest impact on germlings (Vadas et al. 1992, Cervin \& Aberg 1997, Dudgeon \& Petraitis 2005). Ascophyllum has strong non-trophic effects on communities. Canopies dampen physical stress especially in upper shore habitats (Bertness \& Leonard 1997, Leonard 2000), thereby enhancing survivorship and diversity compared to habitats without Ascophyllum (Hacker \& Gaines 1997, Larsen 2012, Watt \& Scrosati 2013).

Historically, Ascophyllum ranged from Baffin Island and northern Norway in the north to New Jersey and northern Portugal in the south in the western and eastern Atlantic Ocean, respectively. Present day southern limits are Long Island Sound and Viano do Castelo in Portugal (Araujo et al. 2012, Keser et al. 2005). Models predicting distributional changes to projected climate change vary. A fine-scale model indicates its distribution responds to non-climatic drivers. A coarser-scale thermal niche model predicts an expanded distribution into the Arctic, little change in the western southern limit, but an $8-10^{\circ}$ northward shift in the eastern North Atlantic (Martinez et al. 2012, Jueterbock et al. 2013).

Two lines of evidence implicate warming as a potential driver of future Ascophyllum population dynamics. In Long Island Sound, growth over 24 years increased with a $1.6^{\circ} \mathrm{C}$ rise to the present ambient temperature of $23^{\circ} \mathrm{C}$ (Keser et al. 2005). Nearby populations in the thermal plume of a power plant decreased growth and increased mortality above $25^{\circ} \mathrm{C}$. An emerging trend is a shift in phenology $\sim 2$ weeks earlier in the spring (S. Dudgeon, pers. obs.), which coincides with a model of gamete release correlated with SST (Bacon \& Vadas 1991). Phenological shifts alter growth, survivorship and the timing and strength of species interactions (Kordas \& Dudgeon 2011, Kordas \& Dudgeon 2009) and are consistent with the "northward shift of the southern limit" hypothesis under climate change.

Ascophyllum shows great longevity; fronds $>20$ years [S. Dudgeon, pers. obs] and genets many decades (Aberg 1992) have been reported. Local populations persist for centuries (Aberg 1992) and phylogeographic architecture indicates Ascophyllum has survived $>1$ glacial/interglacial cycle (Olsen et al. 2010). Anthropogenic impacts from warming (and correlated changes) and harvesting pose the greatest threat to populations and, hence, southern temperate sheltered shore ecosystems that depend on it (Ugarte et al. 2009). Ascophyllum population structure and life history may be a double-edged sword in the context of predicted changes. On one hand, longevity and overlapping generations may buffer populations against losses in genetic diversity due to drift (Araujo et al. 2012), which may enable adaptation. On the other hand, these traits render Ascophyllum-dominated communities vulnerable to ecological catastrophes in a changing environment (Petraitis et al. 2009, Petraitis \& Dudgeon, in review). In these respects, Ascophyllum-dominated shores are particularly useful models for predicting the dynamics of systems whose composition and function depends on a foundation species with top-heavy population structures of many longlived adults and few, poorly recruiting juveniles.

\section{Management and restoration}

The preceding sections have demonstrated that in many regions, macroalgae have experienced contractions of their distributional range and are likely to continue doing so under climate change. Since large algal species are ecological pillars of regional benthic diversity, the threat of losing species and of reduced ecosystem function should represent a motivation for implementing counter measures.

In the face of observed macroalgal declines, a range of options to offset losses have been trialled. Passive management, including creation of protected areas or reduction of coastal pollution, is a common approach yet may not be sufficient if there is an ongoing trend in the stressors associated with the observed decline. For example, bioclimatic modelling studies incorporating future climate scenarios suggest that Macrocystis may become geographically more restricted in the future, and while a move to deeper cooler waters will be possible in some ocean regions, light limitation will generally prevent such movement (Graham et al. 2007a). Thus, while conservation in a preventative sense is a partial solution to the challenge of habitat degradation, the status of many of the world's ecosystems clearly demonstrates that passive conservation is not sufficient (Lotze et al. 2006). In the marine realm, between $50-90 \%$ of ecosystems remain in a degraded state from which they fail to recover despite extensive conservation efforts (Lotze et al. 2006, Lotze et al. 2011). Therefore, there is a need to go beyond conservation to restoration, i.e. not only minimize biodiversity loss, but also recover what has been lost (Young et al. 2005). The application of habitat restoration to different marine systems is, however, very uneven, with kelp forests receiving much less attention than other habitats such as coral reefs or sea grasses, despite similar impacts (Goodsell \& Chapman 2009). Habitat restoration has seen limited success via "replanting" Macrocystis into areas where it has disappeared, suggesting that long term change in habitat suitability has occurred (e.g. Sanderson et al. 2004, but see Campbell et al. 2014). Management of Macrocystis grazers (urchin control), via direct intervention (culling), reintroduction/translocation of predators, and minimum size limits for harvested predators (rock lobster) is also being trialled in Tasmania (Johnson et al. 2011). Evidence for the importance of predators in limiting urchin grazing suggests that managing for predator biomass may be the most widely applicable strategy (Ling et al. 2010). Maintaining viable populations in some regions may require even more radical climate adaption strategies (Koehn et al. 2011), including translocation from "resilient" populations, and consideration of artificial fertilization to maintain nutrient supplies. 
The aim of restoration, i.e. to actively return ecosystem structure and function from a degraded state to a previous, natural condition or less degraded state, is intrinsically ecological and thus requires thorough ecological understanding of the interactions and processes that shape ecosystems to define sensible goals and successfully achieve them (Underwood 1996). Clearly defined goals and quantitative data collected in a way that allows for testing of specific ecological hypotheses are essential (Young et al. 2005, Goodsell \& Chapman 2009).

It is useful to think of restoration as the opposite of an environmental impact and take advantage of the well-developed ecological theory on the subject (e.g. 'Beyond BACI' [Before-After Control-Impact] designs; Underwood 1992) and extend it to restoration ecology (Underwood 1996, Chapman 1999). The "impact" or restoration success can be effectively determined in designs that take into consideration spatial and temporal variability by assessing replicated restored, reference (the 'goal', pristine or less degraded areas) and unrestored ('controls') locations, several times before and after the restoration effort (Chapman 1999). This allows defining clear goals against which to measure success, while, at the same time, taking into account the intrinsic variability of natural systems.

Seeding and/or transplantation of juvenile or adult thalli have been used as techniques for restoring seaweed populations, particularly where propagule supply is low and recruitment is enhanced by the presence of a canopy (e.g. Stekoll \& Deysher 1996, Hernandez-Carmona et al. 2000, Campbell et al. 2014b). The aim is thus to get recruitment and eventually establish a self-sustaining population with similar ecology to those in reference areas (Campbell et al. 2014b). Other techniques focus on artificially modifying the environment (e.g. increasing substratum complexity) to enhance recruitment (e.g. Terawaki et al. 2001, Deysher et al. 2002). However, before embarking in such labourintensive habitat restoration experiments and increasing the spatial extent (Hobbs \& Norton 1996, Peterson et al. 2003), it is necessary to understand what caused the decline of the habitat in the first place, as restoring habitats where the cause(s) of its initial decline have not been removed or reduced would be a waste of resources (Connell et al. 2008, Goodsell \& Chapman 2009). We acknowledge, however, that linking cause and effect may be difficult when the drivers of a decline are multifactorial and interactive as described in the previous sections. Improving environmental conditions such as enhancing water quality may be sufficient to restore lost algal beds directly or indirectly, e.g. by reducing algal turfs and thereby enhancing kelp recruitment (Gorman \& Connell 2009). Indeed, the connection between research and government policy in southern Australia provides an example whereby knowledge (and decision making) across local through global scales provides solutions to some of the most vexing challenges for attaining social goals of sustainability, biological conserva- tion and economic development. For example, by recognising the consequences of breaching co-limitation, managers have the capacity to reduce or even reverse the effects of carbon emissions (Ghedini et al. 2013). This capacity has been recognised by coastal policy makers of South Australia who have redoubled their effort to reduce coastal nitrogen loads by $75 \%$. Engineering improvements to wastewater treatment plants, water-recycling and improved catchment management sought to reduce 5000 tonnes of nitrogen per annum (Gorman et al. 2009). By reducing this local stressor, a resource under local control, the co-limitation of nitrogen with carbon was re-established to dramatically slow the rates of algal mat expansion (Falkenberg et al. 2013). Once the direct factors responsible for macroalgal declines are removed or reduced, understanding the ecological processes and interactions operating in those systems is crucial, given that some indirect processes (e.g. high grazing/low propagule supply Schiel \& Foster 1992, Hernandez-Carmona et al. 2000, Carney et al. 2005) can limit restoration success (Goodsell \& Chapman 2009). Finally, determining what additional ecosystem values are likely to be added through the restoration of a certain habitat-forming species where, in principle, other functionally similar species are still present, will allow informed decisions on the desirability and/ or benefits of restoration (Marzinelli et al. 2013).

\section{Synthesis and conclusions}

The five examples of impact on habitat-forming brown macroalgae all describe an ongoing or expected range shift, most often accompanied by a range contraction. Responses to sets of drivers for this process differ in some aspects but overall show much consensus. Interestingly, in no instance are the "classical" global change components (warming, acidification, UV, eutrophication) considered strong enough stressors to have produced the observed population responses, alone, nor in combination. Interactive effects among global abiotic and regional abiotic and biotic factors seem to be responsible; Fucus vesiculosus seems to respond most to warming and eutrophication interacting with grazing and epibiosis, Laminaria spp. to warming and UV radiation interacting with grazing, diseases and epibiosis, Ecklonia radiata to eutrophication and acidification interacting with competition, Macrocystis pyrifera to warming, nutrients and storms interacting with grazing and epibiosis, as well as acidification interacting with recruitment and Ascophyllum nodosum to warming interacting with phenology and to harvesting. In the majority of cases the biotic interactions seem to amplify the abiotic drivers. In contrast to the brown macroalgae, filamentous competitors, epibionts, mesograzers, and pathogens may benefit from ongoing change. Multiple biotic interactions may also buffer the overall impact when, for instance grazers reduce epibionts, or pathogens affect competitors. Since most of the abiotic factors and the species in a mac- 
roalgal community influence each other, the dynamics in this system will be subject to multiple, connected feedback loops as depicted in Fig. 2. For instance, the direct impact of a nutrient increase will be neutral to moderately beneficial for brown macroalgae in most regions. It will also, however, boost the development of small, fast growing algae in the plankton, as epibionts on macroalgae or as benthic "turf" (including drifting mats of filamentous algae). All of these compete with macroalgae for nutrients and carbon $(\mathrm{CO} 2$ or $\mathrm{HCO}_{3}{ }^{-}$), the former two also for light and the latter for settlement substratum for macroalgal propagules. After a bloom of plankton or turf, the decaying biomass may contribute to hypoxic conditions in the benthos. Blooms of ephemeral algae will be favoured by acidification acting additively or in synergy with eutrophication. The appearance of hypoxia is promoted also by warmer conditions that accelerate microbial re-mineralization activity and, via stable stratification, inhibit the oxygenation of deeper water. Lack of energy driven by nutrient and irradiance depletion through epibionts and plankton will weaken the chemical defenses of macroalgae against herbivory and epibiosis. The latter will permit even more fouling of macroalgal surfaces which, besides the described effects, will also increase drag and hence mechanical vulnerability to storms (the intensity and prevalence of which are expected to increase in many regions). Warming will contribute to the susceptibility of many coldadapted brown macroalgae to herbivory by weakening their defenses and their (compensatory) growth rates in addition to accelerating population growth and activities of many mesograzers. On the other hand, increasing feeding rates may reduce ephemeral competitors (turf, epibionts) which usually are less well defended. The occasional upwelling of hypoxic water bodies could temporarily reduce herbivory while not severely impacting the macroalgae. There is much more potential for ecological amplification or buffering of abiotic environmental change in the system depicted in the figure - even without including forecasted shifts in fishing and harvesting, sedimentation, chemical pollution, hypoxia, UVR or storminess. Warming and nutrient pollution in this review have been suggested to be the most threatening single pressures on brown macroalgae (highlighted in Fig. 2). It is, however, important to note that such factors are often identified at times when macroalgae already show signs of decline. We have observational evidence that global warming and eutrophication may have beneficial impacts on brown macroalgae in winter when temperature tends to be sub-optimal and when no ephemeral competitors are around.

Beside the general consensus, the regional case studies rank some of the stressors differently. This may reflect differential physiological sensitivity of the foundational macroalga in a given region or the species it interacts with. It may also be attributable to different combinations of global and local stressors in the regions considered. Regional stress regimes show differing combinations of global (e.g. warming) and regional (e.g. pollution, fishing) pres- sures (e.g. Firth \& Hawkins 2011).The rate of change and sometimes even the direction of change vary at the temporal scale from seasons to decades and among regions (e.g. BACC 2010, Lima \& Wethey 2012). Biogenic fluctuations (e.g. $\mathrm{pH}, \mathrm{O}_{2}$ ) at different temporal and spatial scale will produce alternating phases of adverse versus benign conditions which may buffer or amplify the impact of a stressor (Cornwall et al. 2014).

The large number of feedback loops represented by interactions among abiotic and biotic pressure make the longterm impact of global change challenging to predict. This renders societal adaptation difficult. On the other hand, interactions between global and local pressures provide a tool for environmental management (Ghedini et al. 2013). Although global warming cannot be stopped or reversed in the coming decades, since most of the above-mentioned stressors act in an additive or even synergistic manner with local-scale stressors, we could reduce the net negative impact of warming, by manipulating those "buttons" which are amenable to local management. Reducing the input of nutrients or even removing extant nutrient loads by, e.g. large scale algal farming, should mitigate the warming effect on fouling organisms. Reducing overfishing in trophically structured systems may reduce population sizes of mesograzers (snails, amphipods, isopods) and alleviate grazing pressure on macroalgae the defenses of which are weakened by warming. Out-planting native genotypes that are less susceptible to warming and/or better defended might help restoring lost macroalgal fields. While reducing local stress is perhaps the only realistic option for short to mid-term environmental management, without significant reduction in greenhouse gas emissions, the long-term prospects for large brown macroalgae in many locations seem limited.

Acknowledgements: We gratefully acknowledge financial support by ARC grants to S. Connell and P.D. Steinberg and a NSF LTREB grant to S.R. Dudgeon, and the comments of the editor and an anonymous reviewer.

\section{References}

Aberg, P. (1992): A demographic-study of 2 populations of the seaweed Ascophyllum-nodosum. - Ecology 73: 1473-1487.

Airoldi, L., Balata, D. \& Beck, M.W. (2008): The Gray Zone: Relationships between habitat loss and marine diversity and their applications in conservation. - J. Exp. Mar. Biol. Ecol. 366: 8-15.

Amano, H., Sakaguchi, K., Maegawa, M. \& Noda, H. (1996): The use of a monoclonal antibody for the detection of fungal parasite, Pythium sp, the causative organism of red rot disease, in seawater from Porphyra cultivation farms. - Fish. Sci. 62: 556-560.

Araujo, R., Sousa-Pinto, I., Serrao, E.A. \& Aberg, P. (2012): Recovery after trampling disturbance in a canopy-forming seaweed population. - Mar. Biol. 159: 697-707. 
BACC Author team (2010): Assessment of Climate Change for the Baltic Sea Basin. Springer, Heidelberg.

Bacon, L.C. \& Vadas, R.L. (1991): A model for gamete release in Ascophyllum-nodosum (Phaeophyta). - J. Phycol. 27: 166-173.

Banin, E., Vassilakos, D., Orr, E., Martinez, R.J. \& Rosenberg, E. (2002): Superoxide dismutase is a virulence factor produced by the coral bleaching pathogen Vibrio shiloi. - Curr. Microbiol. 46: 418-422.

Bartsch, I., Wiencke, C., Bischof, K., Buchholz, C.M., Buck, B.H., Eggert, A., Feuerpfeil, P., Hanelt, D., Jacobsen, S., Karez, R., Karsten, U., Molis, M., Roleda, M.Y., Schubert, H., Schumann, R., Valentin, K., Weinberger, F. \& Wiese, J. (2008): The genus Laminaria sensu lato: recent insights and developments. - Eur. J. Phycol. 43: 1-86.

Bartsch, I., Vogt, J., Pehlke, C. \& Hanelt, D. (2013): Prevailing sea surface temperatures inhibit summer reproduction of the kelp Laminaria digitata at Helgoland (North Sea). - J. Phycol. 49: 1061-1073.

Berger, R., Henriksson, E., Kautsky, L. \& Malm, T. (2003): Effects of filamentous algae and deposited matter on the survival of Fucus vesiculosus L. germlings in the Baltic Sea. - Aquatic Ecol. 37: 1-11.

Berger, R., Bergstrom, L., Graneli, E. \& Kautsky, L. (2004): How does eutrophication affect different life stages of Fucus vesiculosus in the Baltic Sea? A conceptual model. - Hydrobiologia 514: 243-248.

Bertness, M.D. \& Leonard, G.H. (1997): The role of positive interactions in communities: Lessons from intertidal habitats. Ecology 78: 1976-1989.

Bolton, J., Robertson-Andersson, D., Shuuluka, D. \& Kandjengo, L. (2009): Growing Ulva (Chlorophyta) in integrated systems as a commercial crop for abalone feed in South Africa: a SWOT analysis. - J. Appl. Phycol. 21: 575-583.

Boots, M. (2008): Fight or learn to live with the consequences? Trends Ecol. Evol. 23: 248-250.

Breeman, A.M. (1988): Relative importance of temperature and other factors in determining geographic boundaries of seaweeds: experimental and phenological evidence. - Helgol. Meeresunters. 42: 199-241.

Brown, C.J., Saunders, M.I., Possingham, H.P. \& Richardson, A.J. (2013): Managing for interactions between local and global stressors of ecosystems. - PLoS ONE 8: e65765. doi:10.1371/ journal.pone.0065765.

Bulleri, F. \& Airoldi, L. (2005): Artificial marine structures facilitate the spread of a non-indigenous green alga, Codium fragile ssp. tomentosoides, in the north Adriatic Sea. - J. Appl. Ecol. 42: 1063-1072.

Bulleri, F. \& Chapman, M.G. (2010): The introduction of coastal infrastructure as a driver of change in marine environments. J. Appl. Ecol. 47: 26-35.

Burdon, J.J. (1987): Diseases and plant population biology. Cambridge University Press, Cambridge, United Kingdom.

Campbell, A.H. (2011): The ecology of bacterially-mediated bleaching in a chemically-defended seaweed. - In: School of Biological, Earth and Environmental Sciences. pp. 188. University of New South Wales, Sydney.

Campbell, A.H., Harder, T., Nielsen, S., Kjelleberg, S. \& Steinberg, P.D. (2011): Climate change and disease: bleaching in a chemically-defended seaweed. - Global Change Biol. 17: 2958-2970.

Campbell, A.H., Vergés, A. \& Steinberg, P.D. (2014a): Demographic consequences of disease in a habitat-forming seaweed and impacts on interactions between natural enemies. - Ecology 95: 142-152.
Campbell, A.H., Marzinelli, E.M., Verges, A., Coleman, M. \& Steinberg, P.D. (2014b): Towards restoration of missing underwater forests. - PLoS One 9: e84106.

Carney, L.T., Waaland, J.R., Klinger, T. \& Ewing, K. (2005): Restoration of the bull kelp Nereocystis luetkeana in nearshore rocky habitats. - Mar. Ecol. Progr. Ser. 302: 49-61.

Case, R.J., Longford, S.R., Campbell, A.H., Low, A., Tujula, N.A., Steinberg, P.D. \& Kjelleberg, S. (2011): Temperature induced bacterial virulence and bleaching disease in a chemically defended marine macroalga. - Environ. Microbiol. 13: 529-537.

Cervin, G. \& Aberg, P. (1997): Do littorinids affect the survival of Ascophyllum nodosum germlings? - J. Exp. Mar. Biol. Ecol. 218: 35-47.

Chapman, M.G. (1999): Improving sampling designs for measuring restoration in aquatic habitats. - J. Aquatic Ecosyst. Stress Recovery 6: 235-251.

Christie, H., Jorgensen, N.M., Norderhaug, K.M. \& Waage-Nielsen, E. (2003): Species distribution and habitat exploitation of fauna associated with kelp (Laminaria hyperborea) along the Norwegian coast. - J. Mar. Biol. Assoc. U.K. 83: 687-699.

Cole, R.G. \& Babcock, R.C. (1996): Mass mortality of a dominant kelp (Laminariales) at Goat Island, North-eastern New Zealand. - Mar. Freshwater Res. 47: 907-911.

Coleman, M.A., Kelaher, B.P., Steinberg, P.D. \& Millar, A.J.K. (2008): Absence of a large brown macroalga on urbanized rocky reefs around Sydney, Australia, and evidence for historical decline. - J. Phycol. 44: 897-901.

Coleman, M.A., Roughan, M., Macdonald, H.S., Connell, S.D., Gillanders, B.M., Kelaher, B.P. \& Steinberg, P.D. (2011): Variation in the strength of continental boundary currents determines continent-wide connectivity in kelp. - J. Ecol. 99: 1026-1032.

Connell, S.D., Russell, B.D., Turner, D.J., Shepherd, S.A., Kildea, T., Miller, D., Airoldi, L. \& Cheshire, A. (2008): Recovering a lost baseline: missing kelp forests from a metropolitan coast. Mar. Ecol. Progr. Ser. 360: 63-72.

Connell, S.D. \& Irving, A.D. (2008): Integrating ecology with biogeography using landscape characteristics: a case study of subtidal habitat across continental Australia. - J. Biogeogr. 35: 1608-1621.

Connell, S.D. \& Russell, B.D. (2010): The direct effects of increasing $\mathrm{CO}_{2}$ and temperature on non-calcifying organisms: increasing the potential for phase shifts in kelp forests. - Proc. R. Soc. B, Biol. Sci. 277: 1409-1415.

Connell, S.D., Kroeker, K.J., Fabricius, K.E., Kline, D.I. \& Russell, B.D. (2013): The other ocean acidification problem: $\mathrm{CO}_{2}$ as a resource among competitors for ecosystem dominance. - Phil. Trans. R. Soc. B, Biol. Sci. 368: 20120442.

Connell, S.D., Foster, M.S. \& Airoldi, L. (2014): What are algal turfs? Towards a better description of turfs. - Mar. Ecol. Progr. Ser. 495: 299-307.

Cook, T., Folli, M., Klinck, J., Ford, S. \& Miller, J. (1998): The Relationship Between Increasing Sea-surface Temperature and the Northward Spread of Perkinsus marinus(Dermo). Disease Epizootics in Oysters. - Estuarine, Coastal and Shelf Sci. 46: 587-597.

Cornwall, C.E., Boyd, P.W., Mcgraw, C.M., Hepburn, C.D., Pilditch, C.A., Morris, J.N., Smith, A.M. \& Hurd, C.L. (2014): Diffusion Boundary Layers Ameliorate the Negative Effects of Ocean Acidification on the Temperate Coralline Macroalga Arthrocardia corymbosa. - PloS One 9. 
Correa, J. \& Flores, V. (1995): Whitening, thallus decay and fragmentation in Gracilaria chilensis associated with an endophytic amoeba. - J. Appl. Phycol. 7: 421-425.

Correa, J.A. \& Mclachlan, J.R. (1992): Endophytic algae of Chondrus crispus (Rhodophyta). IV. Effects on the host following infections by Acrochaete operculata and A. heteroclada (Chlorophyta). - Mar. Ecol. Progr. Ser. 81: 73-87.

Correa, J.A., Flores, V. \& Sanchez, P. (1993): Deformative disease in Iridaea laminarioides (Rhodophyta): Gall development associated with an endophytic cyanobacterium. - J. Phycol. 29: 853-860.

Correa, J.A., Flores, V. \& Garrido, J. (1994): Green patch disease in Iridaea laminarioides (Rhodophyta) caused by Endophyton sp. (Chlorophyta). - Dis. Aquat. Organ. 19: 203-213.

Cousens, R. (1984): Estimation of annual production by the intertidal brown alga Ascophyllum nodosum (L.) Lejolis. - Bot. Mar. 27: 217-227.

Craigie, J.S. \& Correa, J.A. (1996): Etiology of infectious diseases in cultivated Chondrus crispus (Gigartinales, Rhodophyta). Hydrobiologia 326-327: 97-104.

Crain, C.M., Kroeker, K. \& Halpern, B.S. (2008): Interactive and cumulative effects of multiple human stressors in marine systems. - Ecol. Lett. 11: 1304-1315.

Cronin, G. 2001. Resource allocation in seaweeds and marine invertebrates: chemical defense patterns in relation to defense theories. - In: McClintock, J.B. \& Baker, B.J. (eds.), Marine Chemical Ecology, pp. 325-353. CRC Press, New York.

Cyr, H. \& Pace, M.L. (1993): Magnitude and patterns of herbivory in aquatic and terrestrial ecosystems. - Nature 361: 148-150.

Dayton, P.K., Currie, V., Gerrodette, T. \& Keller, B. (1984): Patch dynamics and stability of some Californian kelp communities. - Ecol. Monogr. 54: 253-289.

Dayton, P.K., Tegner, M., Parnell, P. \& Edwards, P. (1992): Temporal and spatial patterns of disturbance and recovery in a kelp forest community. - Ecol. Monogr. 62: 421-445.

Dean, T.A., Schroeter, S.C. \& Dixon, J.D. (1984): Effects of grazing by two species of sea urchins (Strongylocentrotusfranciscanus and Lytechinus anamesus) on recruitment and survival of two species of kelp (Macrocystis pyrifera and Pterygophora californica). - Mar. Biol. 78: 301-313.

Deysher, L.E., Dean, T.A., Grove, R.S. \& Jahn, A. (2002): Design considerations for an artificial reef to grow giant kelp (Macrocystis pyrifera) in Southern California. - ICES J. Mar. Sci. 59: S201-S207.

Doney, S.C., Ruckelshaus, M., Duffy, J.E., Barry, J.P., Chan, F., English, C.A., Galindo, H.M., Grebmeier, J.M., Hollowed, A.B., Knowlton, N., Polovina, J., Rabalais, N.N., Sydeman, W.J. \& Talley, L.D. (2012): Climate Change Impacts on Marine Ecosystems. - Ann. Rev. Mar. Sci. 4: 11-37.

Dudgeon, S.R. \& Petraitis, P.S. (2005): Early life demography of a foundation species and the community-level implications. Oikos 109: 405-415.

Easton, L. (1995): Ecklonia radiata dieback: the role of viral pathogens. pp. 129. University of Auckland, Auckland.

Easton, L.M., Lewis, G.D. \& Pearson, M.N. (1997): Virus-like particles associated with dieback symptoms in the brown alga Ecklonia radiata. - Dis. Aquat. Organ. 30: 217-222.

Edyvane, K. (2003): Conservation Monitoring and Recovery of Threatened Giant Kelp (Macrocystis pyrifera) Beds in Tasmania - Final Report. Department of Primary Industries, Water and Environment, Hobart.
Eggert, A.2012. Seaweed responses to temperature. - In: Wiencke, C. \& Bischof, K. (eds.), Seaweed biology: Novel insights into ecophysiology, ecology and utilization, pp. 510. SpringerVerlag, Berlin, Heidelberg.

Engkvist, E., Malm, T. \& Nilsson, J. (2004): Interaction between isopod grazing and wave action: a structuring force in macroalgal communities in the southern Baltic Sea. - Aquat. Ecol. 38: 403-413.

Epbc-Act. (1999): Environment Protection and Biodiversity Conservation Act 1999. Act No. 91 of 1999. (ed. by C. Aust. Gov., Australia). http://www.comlaw.gov.au/Details/C2014C00506 .

Estes, J.A., Tinker, M.T., Williams, T.M. \& Doak, D.F. (1998): Killer whale predation on sea otters linking oceanic and nearshore ecosystems. - Science 282: 473-476.

Falkenberg, L.J., Russell, B.D. \& Connell, S.D. (2013): Contrasting resource limitations of marine primary producers: implications for competitive interactions under enriched $\mathrm{CO} 2$ and nutrient regimes. - Oecologia 172: 575-583.

Fernandes, N., Steinberg, P.D., Rusch, D., Kjelleberg, S. \& Thomas, T. (2012): Community structure and functional gene profile of bacteria on healthy and diseased thalli or the red seaweed Delisea pulchra. - PLoS One 7: e50854.

Firth, L.B. \& Hawkins, S.J. (2011): Introductory comments Global change in marine ecosystems: Patterns, processes and interactions with regional and local scale impacts. - J. Exp. Mar. Biol. Ecol. 400: 1-6.

Ford, S.F. (1996): Range expansion by the oyster parasite Perkinsus marinus into the Northeastern United States: Response to climate change? - J. Shellfish Res. 15: 45-56.

Foster, M.S. \& Schiel, D.R. (1988): Kelp communities and sea otters: keystone species or just another brick in the wall? - In: VanBlaricom, G.R. \& Estes, J.A. (eds.), The community ecology of sea otters. Ecol. Stud. 65, pp. 92-107. Springer Verlag, New York.

Gachon, C.M.M., Sime-Ngando, T., Strittmatter, M., Chambouvet, A. \& Kim, G.H. (2010): Algal diseases: spotlight on a black box. - Trends Plant Sci. 15: 633-640.

Gaitán-Espitia, J.D., Hancock, J.R., Padilla-Gamiño, J.L., Rivest, E.B., Blanchette, C.A., Reed, D.C. \& Hofmann, G.E. (2014): Interactive effects of elevated temperature and $\mathrm{pCO}_{2}$ on earlylife-history stages of the giant kelp Macrocystis pyrifera. J. Exp. Mar. Biol. Ecol. 457: 51-58.

Gemmill, A.W. \& Read, A.F. (1998): Counting the cost of disease resistance. - Trends Ecol. Evol. 13: 8-9.

Ghedini, G., Russell, B.D. \& Connell, S.D. (2013): Managing Local Coastal Stressors to Reduce the Ecological Effects of Ocean Acidification and Warming. - Water 5: 1653-1661.

Goodsell, P.J. \& Chapman, M.G.2009. Rehabilitation of habitat and the value of artificial reefs. - In: Wahl, M. (ed.), Marine Hard Bottom Communities: Patterns, Dynamics, Diversity, and Change, pp. 333-344.

Gorman, D., Russell, B.D. \& Connell, S.D. (2009): Land-to-sea connectivity: linking human-derived terrestrial subsidies to subtidal habitat change on open rocky coasts. - Ecol. Appl. 19: 1114-1126.

Gorman, D. \& Connell, S.D. (2009): Recovering subtidal forests in human-dominated landscapes. - J. Appl. Ecol. 46: 1258-1265.

Graewe, U., Friedland, R. \& Burchard, H. (2013): The future of the western Baltic Sea: two possible scenarios. - Ocean Dynam. 63: 901-921. 
Graham, M.H., Kinlan, B.P., Druehl, L.D., Garske, L.E. \& Banks, S. (2007a): Deep-water kelp refugia as potential hotspots of tropical marine diversity and productivity. - Proc. Nat. Acad. Sci. U.S.A. 104: 16576-16580.

Graham, M.H., Vasquez, J.A. \& Buschmann, A.H. (2007b): Global ecology of the giant kelp Macrocystis: from ecotypes to ecosystems. - Oceanogr. Mar. Biol. Ann. Rev. 45: 39-88.

Gutow, L., Rahman, M.M., Bartl, K., Saborowski, R., Bartsch, I. \& Wiencke, C. (2014): Ocean acidification affects growth but not nutritional quality of the seaweed Fucus vesiculosus (Phaeophyceae, Fucales). - J. Exp. Mar. Biol. Ecol. 453: 84-90.

Hacker, S.D. \& Gaines, S.D. (1997): Some implications of direct positive interactions for community species diversity. - Ecology 78: 1990-2003.

Haggitt, T.R. \& Babcock, R.C. (2003): The role of grazing by the lysianassid amphipod Orchomenella aahu in dieback of the kelp Ecklonia radiata in north-eastern New Zealand. - Mar. Biol. 143: 1201-1211.

Hall-Spencer, J.M., Rodolfo-Metalpa, R., Martin, S., Ransome, E., Fine, M., Turner, S.M., Rowley, S.J., Tedesco, D. \& Buia, M.-C. (2008): Volcanic carbon dioxide vents show ecosystem effects of ocean acidification. - Nature: doi:10.1038/nature07051.

Harley, C.D.G., Anderson, K.M., Demes, K.W., Jorve, J.P., Kordas, R.L., Coyle, T.A. \& Graham, M.H. (2012a): Effects of climate change on global seaweed communities. - J. Phycol. 48: 1064-1078.

Harley, C.D.G., Anderson, K.M., Demes, K.W., Jorve, J.P., Kordas, R.L., Coyle, T.A. \& Graham, M.H. (2012b): Effects of climate change on global seaweed communities. - J. Phycol. 48: 1064-1078.

Harpole, W.S., Ngai, J.T., Cleland, E.E., Seabloom, E.W., Borer, E.T., Bracken, M.E.S., Elser, J.J., Gruner, D.S., Hillebrand, H., Shurin, J.B. \& Smith, J.E. (2011): Nutrient co-limitation of primary producer communities. - Ecol. Lett. 14: 852-862.

Harrold, C. \& Reed, D.C. (1985): Food availability, sea urchin grazing, and kelp forest community structure. - Ecology 66: 1160-1169.

Harvell, C.D., Kim, K., Quirolo, C., Weir, J. \& Smith, G. (2001): Coral bleaching and disease: contributors to 1998 mass mortality in Briareum asbestinum (Octocorallia, Gorgonacea). Hydrobiologia 460: 97-104.

Harvell, C.D., Mitchell, C.E., Ward, J.R., Altizer, S., Dobson, A.P., Ostfeld, R.S. \& Samuel, M.D. (2002): Climate warming and disease risks for terrestrial and marine biota. - Science 296: 2158-2162.

Hawkins, S.J., Sugden, H.E., Mieszkowska, N., Moore, P.J., Poloczanska, E., Leaper, R., Herbert, R.J.H., Genner, M.J., Moschella, P.S., Thompson, R.C., Jenkins, S.R., Southward, A.J. \& Burrows, M.T. (2009): Consequences of climate-driven biodiversity changes for ecosystem functioning of North European rocky shores. - Mar. Ecol. Progr. Ser. 396: 245-259.

Hay, M.E. (1991): Marine-terrestrial contrasts in the ecology of plant chemical defenses against herbivores. - Trends Ecol. Evol. 6: 362-365.

Hay, M.E. (1997): The ecology and evolution of seaweed-herbivore interactions on coral reefs. - Coral Reefs 16, Suppl.: S67-S76.

Hemmi, A., Makinen, A., Jormalainen, V. \& Honkanen, T. (2005): Responses of growth and phlorotannins in Fucus vesiculosus to nutrient enrichment and herbivory. - Aquat. Ecol. 39: 201-211.

Hernandez-Carmona, G., Garcia, O., Robledo, D. \& Foster, M. (2000): Restoration techniques for Macrocystis pyrifera
(Phaeophyceae) populations at the southern limit of their distribution in Mexico. - Bot. Mar. 43: 273-284.

Hernandez, J.C., Clemente, S., Girard, D., Perez-Ruzafa, A. \& Brito, A. (2010): Effect of temperature on settlement and postsettlement survival in a barrens-forming sea urchin. - Mar. Ecol. Progr. Ser. 413: 69-80.

Hillerislambers, J., Harsch, M.A., Ettinger, A.K., Ford, K.R. \& Theobald, E.J. (2013): How will biotic interactions influence climate change-induced range shifts? - Ann. New York Acad. Sci. 1297: 112-125.

Hobbs, R.J. \& Norton, D.A. (1996): Towards a conceptual framework for restoration ecology. - Restor. Ecol. 4: 93-110.

Hobday, A.J. (2000): Abundance and dispersal of drifting kelp Macrocystis pyrifera rafts in the Southern California Bight. Mar. Ecol. Progr. Ser. 195: 101-116.

Hobday, A.J. \& Pecl, G.T. (2014): Identification of global marine hotspots: sentinels for change and vanguards for adaptation action. - Rev. Fish Biol. Fish. 24: 415-425. DOI: 10.1007/ s11160-013-9326-6.

Ipcc-Ar5. (2014): Summary for Policymakers. - In: Climate Change 2014: Impacts, Adaptation, and Vulnerability. -.

Ipcc, W.G.I. (2013): Contribution to the IPCC Fifth Assessment Report; Climate Change 2013: The Physical Science Basis; Summary for Policymakers, pp. 36.

Jackson, J.B.C. (2001): What was natural in the coastal oceans? Proc. Nat. Acad. Sci. U.S.A. 98: 5411-5418.

Johnson, C.R., Banks, S.C., Barrett, N.S., Cazassus, F., Dunstan, P.K., Edgar, G.J., Frusher, S.D., Gardner, C., Haddon, M., Helidoniotis, F., Hill, K.L., Holbrook, N.L., Hosie, G.W., Last, P.R., Ling, S.D., Melbourne-Thomas, J., Miller, K., Pecl, G.T., Richardson, A.J., Ridgway, K.R., Rintoul, S.R., Ritz, D.A., Ross, D.J., Sanderson, J.C., Shepherd, S.A., Slotwinski, A., Swadling, K.M. \& Taw, N. (2011): Climate change cascades: Shifts in oceanography, species' ranges and subtidal marine community dynamics in eastern Tasmania. - J. Exp. Mar. Biol. Ecol.doi:10.1016/j.jembe.2011.02.032.

Jueterbock, A., Tyberghein, L., Verbruggen, H., Coyer, J.A., Olsen, J.L. \& Hoarau, G. (2013): Climate change impact on seaweed meadow distribution in the North Atlantic rocky intertidal. Ecol. Evol. 3: 1356-1373.

Kakita, H. \& Kamishima, H. (2006): Effects of Environmental Factors and Metal Ions on Growth of the Red Alga Gracilaria chorda Holmes (Gracilariales, Rhodophyta). - J. Appl. Phycol. 18: 469-474.

Karez, R. \& Chapman, A.R.O. (1998): A competitive hierarchy model integrating roles of physiological competence and competitive ability does not provide a mechanistic explanation for the zonation of three intertidal Fucus species in Europe. - Oikos 81: 471-494.

Karez, R., Engelbert, S. \& Sommer, U. (2000): 'Co-consumption' and 'protective coating': two new proposed effects of epiphytes on their macroalgal hosts in mesograzer-epiphyte-host interactions. - Mar. Ecol. Progr. Ser. 205: 85-93.

Keeling, R.F., Kortzinger, A. \& Gruber, N. (2010): Ocean Deoxygenation in a Warming World. - Ann. Rev. Mar. Sci. 2: 199-229.

Kersen, P., Kotta, J., Bucas, M., Kolesova, N. \& Dekere, Z. (2011): Epiphytes and associated fauna on the brown alga Fucus vesiculosus in the Baltic and the North Seas in relation to different abiotic and biotic variables. - Mar. Ecol. Evol. Perspect. 32: $87-95$. 
Keser, M., Swenarton, J.T. \& Foertch, J.F. (2005): Effects of thermal input and climate change on growth of Ascophyllum nodosum (Fucales, Phaeophyceae) in eastern Long Island Sound (USA). - J. Sea Res. 54: 211-220.

Klinkert, B. \& Narberhaus, F. (2009): Microbial thermosensors. Cell. Mol. Life Sci. 66: 2661-2676.

Koch, M., Bowes, G., Ross, C. \& Zhang, X.-H. (2013): Climate change and ocean acidification effects on seagrasses and marine macroalgae. - Global Change Biol. 19: 103-132.

Koehn, J.D., Hobday, A.J., Pratchett, M.S. \& Gillanders, B.M. (2011): Climate change and Australian marine and freshwater environments, fishes and fisheries: synthesis and options for adaptation. - Mar. Freshwater Res. 62: 1148-1164.

Konkel, M.E. \& Tilly, K. (2000): Temperature-regulated expression of bacterial virulence genes. - Microbes Infect. 2: 157-166.

Kordas, R.L. \& Dudgeon, S. (2009): Modeling variation in interaction strength between barnacles and fucoids. - Oecologia 158: $717-731$

Kordas, R.L. \& Dudgeon, S. (2011): Dynamics of species interaction strength in space, time and with developmental stage. Proc. Roy. Soc. B, Biol. Sci. 278: 1804-1813.

Korpinen, S., Honkanen, T., Vesakoski, O., Hemmi, A., Koivikko, R., Loponen, J. \& Jormalainen, V. (2007): Macroalgal communities face the challenge of changing biotic interactions: Review with focus on the Baltic Sea. - Ambio 36: 203-211.

Krumhansl, K.A., Lee, J.M. \& Scheibling, R.E. (2011): Grazing damage and encrustation by an invasive bryozoan reduce the ability of kelps to withstand breakage by waves. - J. Exp. Mar. Biol. Ecol. 407: 12-18.

Lafferty, K.D., Porter, J.W. \& Ford, S.E. (2004): Are diseases increasing in the ocean? - Ann. Rev. Ecol. Evol. Syst. 35: 31-54.

Largo, D.B., Fukami, K. \& Nishijima, T. (1999): Time-dependent attachment mechanism of bacterial pathogen during ice-ice infection in Kappaphycus alvarezii (Gigartinales, Rhodophyta). - J. Appl. Phycol. 11: 129-136.

Larsen, P.F. (2012): The macroinvertebrate fauna of rockweed (Ascophyllum nodosum)-dominated low-energy rocky shores of the northern Gulf of Maine. - J. Coast. Res. 28: 36-42.

Lehvo, A., Back, S. \& Kiirikki, M. (2001): Growth of Fucus vesiculosus L. (Phaeophyta) in the northern Baltic proper: Energy and nitrogen storage in seasonal environment. - Bot. Mar. 44: 345-350.

Leidenberger, S., Harding, K. \& Jonsson, P.R. (2012): Ecology and distribution of the isopod genus Idotea in the Baltic sea: key species in a changing environment. - J. Crustacean Biol. 32: 359-381.

Leonard, G.H. (2000): Latitudinal variation in species interactions: A test in the New England rocky intertidal zone.- Ecology 81: 1015-1030.

Lima, F.P., Ribeiro, P.A., Queiroz, N., Hawkins, S.J. \& Santos, A.M. (2007): Do distributional shifts of northern and southern species of algae match the warming pattern? - Global Change Biol. 13: 2592-2604.

Lima, F.P. \& Wethey, D.S. (2012): Three decades of high-resolution coastal sea surface temperatures reveal more than warming. Nat. Commun. 3: 704-716.

Ling, S.D. (2008): Range expansion of a habitat-modifying species leads to loss of taxonomic diversity: a new and impoverished reef state. - Oecologia 156: 883-894. DOI: 10.1007/ s00442-008-1043-9.

Ling, S.D., Johnson, C.R., Ridgway, K., Hobday, A.J. \& Haddon, M. (2009): Climate driven range extension of a sea urchin: inferring future trends by analysis of recent population dynamics. - Global Change Biol. 15: 719 - 731.

Ling, S.D., Ibbott, S. \& Sanderson, J.C. (2010): Recovery of canopy-forming macroalgae following removal of the enigmatic grazing sea urchin Heliocidaris erythrogramma. - J. Exper. Mar. Biol. Ecol. 395: 135-146.

Littler, M.M. \& Littler, D.S. (1995): Impact of CLOD pathogen on Pacific coral reefs. - Science 267: 1356-1360.

Lotze, H.K., Lenihan, H.S., Bourque, B.J., Bradbury, R.H., Cooke, R.G., Kay, M.C., Kidwell, S.M., Kirby, M.X., Peterson, C.H. \& Jackson, J.B.C. (2006): Depletion, degradation, and recovery potential of estuaries and coastal seas. - Science 312: 1806-1809.

Lotze, H.K., Coll, M., Magera, A.M., Ward-Paige, C. \& Airoldi, L. (2011): Recovery of marine animal populations and ecosystems. - Trends Ecol. Evol. 26: 595-605.

Martinez, B., Viejo, R.M., Carreno, F. \& Aranda, S.C. (2012): Habitat distribution models for intertidal seaweeds: responses to climatic and non-climatic drivers. - J. Biogeogr. 39: 1877-1890.

Marzinelli, E.M., Campbell, A.H., Verges, A., Coleman, M.A., Kelaher, B.P. \& Steinberg, P.D. (2013): Restoring seaweeds: does the declining fucoid Phyllospora comosa support different biodiversity than other habitats? - J. Appl. Phycol. 26: 1089-1096.

Mathieson, A.C., Penniman, C.A., Busse, P.K. \& Tvetergallagher, E. (1982): Effects of ice on Ascophyllum nodosum within the Great Bay estuary system of New Hampshire, Maine. - J. Phycol. 18: 331-336.

Molis, M., Enge, A. \& Karsten, U. (2010): Grazing impact of, and indirect interactions between mesograzers associated with kelp (Laminaria digitata). - J. Phycol. 46: 76-84.

Müller, R., Wiencke, C. \& Bischof, K. (2008): Interactive effects of UV radiation and temperature on microstages of Laminariales (Phaeophyceae) from the Arctic and North Sea. - Climate Res. 37: 203-213.

Müller, R., Laepple, T., Bartsch, I. \& Wiencke, C. (2009): Impact of oceanic warming on the distribution of seaweeds in polar and cold-temperate waters. - Bot. Mar. 52: 617-638.

Myers, J.H. \& Kuken, B. (1995): Changes in the fecundity of tent caterpillars: a correlated character of disease resistance or sublethal effect of disease? - Oecologia 103: 475-480.

Namba, T. (1984): Competitive co-existence in a seasonally fluctuating environment. - J. Theoretical Biol. 111: 369-386.

Nellemann, C., Hain, S. \& Alder, J.E. (2008): In Dead Water Merging of climate change with pollution, over-harvest, and infestations in the world's fishing grounds. (ed. by U.N.E. Programme), pp. 64.

Nicastro, K.R., Zardi, G.I., Teixeira, S., Neiva, J., Serrao, E.A. \& Pearson, G.A. (2013): Shift happens: trailing edge contraction associated with recent warming trends threatens a distinct genetic lineage in the marine macroalga Fucus vesiculosus. BMC Biology 11: 6 .

Nilsson, J., Engkvist, R. \& Persson, L.E. (2004): Long-term decline and recent recovery of Fucus populations along the rocky shores of southeast Sweden, Baltic Sea. - Aquatic Ecol. 38: 587-598.

Norderhaug, K.M. \& Christie, H. (2009): Sea urchin grazing and kelp re-vegetation in the NE Atlantic. - Mar. Biol. Res. 5: 515-528.

O'Brien, J.M., Krumhansl, K.A. \& Scheibling, R.E. (2013): Invasive bryozoan alters interaction between a native grazer and its algal food. - J. Mar. Biol. Assoc. U. K. 95: 1393-1400. 
Olsen, J.L., Zechman, F.W., Hoarau, G., Coyer, J.A., Stam, W.T., Valero, M. \& Aberg, P. (2010): The phylogeographic architecture of the fucoid seaweed Ascophyllum nodosum: an intertidal 'marine tree' and survivor of more than one glacial-interglacial cycle. - J. Biogeogr. 37: 842-856.

Park, C., Kakinuma, M. \& Amano, H. (2006): Forecasting infections of the red rot disease on Porphyra yezoensis Ueda (Rhodophyta) cultivation farms. - J. Appl. Phycol. 18: 295-299.

Park, C., Park, K., Baek, J. \& Hwang, E. (2008): The occurrence of pinhole disease in relation to developmental stage in cultivated Undaria pinnatifida (Harvey) Suringar (Phaeophyta) in Korea. - J. Appl. Phycol. 20: 485-490.

Park, T. (1948): Experimental studies of interspecific competition I. Competition between populations of the flour beetles, Tribolium confusum and Tribolium castaneum. - Ecol. Monogr. 18: 267-307.

Parker, J.D. \& Hay, M.E. (2005): Biotic resistance to plant invasions? Native herbivores prefer non-native plants. - Ecol. Lett. 8: 959-967.

Parker, J.D., Burkepile, D.E. \& Hay, M.E. (2006): Opposing effects of native and exotic herbivores on plant invasions. - Science 311: 1459-1461.

Parmesan, C. \& Yohe, G. (2003): A globally coherent fingerprint of climate change impacts across natural systems. - Nature 421: 37-42.

Parnell, P.E., Miller, E.F., Lennart-Cody, C.E., Dayton, P.K., Carter, M.L. \& Stebbins, T.D. (2010): The response of giant kelp (Macrocystis pyrifera) in southern California to low-frequency climate forcing. - Limnol. Oceanogr. 55: 2686-2702.

Pavia, H., Cervin, G., Lindgren, A. \& Aberg, P. (1997): Effects of UV-B radiation and simulated herbivory on phlorotannins in the brown alga Ascophyllum nodosum. - Mar. Ecol. Progr. Ser. 157: 139-146.

Peters, A.F. \& Schaffelke, B. (1996): Streblonema (Ectocarpales, Phaeophyceae) infection in the kelp Laminaria saccharina (Laminariales, Phaeophyceae) in the western Baltic. Hydrobiologia 326-327: 111-116.

Peterson, C.H., Kneib, R.T. \& Manen, C.A. (2003): Scaling restoration actions in the marine environment to meet quantitative targets of enhanced ecosystem services. - Mar. Ecol. Progr. Ser. 264: 173-175.

Petraitis, P.S., Methratta, E.T., Rhile, E.C., Vidargas, N.A. \& Dudgeon, S.R. (2009): Experimental confirmation of multiple community states in a marine ecosystem. - Oecologia 161: 139-148.

Poloczanska, E.S., Brown, C.J., Sydeman, W.J., Kiessling, W., Schoeman, D.S., Moore, P.J., Brander, K., Bruno, J.F., Buckley, L.B., Burrows, M.T., Duarte, C.M., Halpern, B.S., Holding, J., Kappel, C.V., O'connor, M.I., Pandolfi, J.M., Parmesan, C., Schwing, F., Thompson, S.A. \& Richardson, A.J. (2013): Global imprint of climate change on marine life. - Nat. Climate Change 3: 919-925.

Pomeroy, L.R. \& Wiebe, W.J. (2001): Temperature and substrates as interactive limiting factors for marine heterotrophic bacteria. - Aquat. Microbial Ecol. 23: 187-204.

Poore, A.G.B., Campbell, A.H., Coleman, R.A., Edgar, G.J., Jormalainen, V., Reynolds, P.L., Sotka, E.E., Stachowicz, J.J., Taylor, R.B., Vanderklift, M.A. \& Duffy, J.E. (2012): Global patterns in the impact of marine herbivores on benthic primary producers. - Ecol. Lett. 15: 912-922.
Prenter, J., Macneil, C., Dick, J.T.A. \& Dunn, A.M. (2004): Roles of parasites in animal invasions. - Trends Ecol. Evol. 19: 385-390.

Raybaud, V., Beaugrand, G., Goberville, E., Delebecq, G., C., D., Valero, M., Davoult, M., Morin, P. \& Gevaer, F. (2013): Decline in Kelp in West Europe and Climate. - PLoS One 8: e66044.

Rioux, L.-E., Turgeon, S.L. \& Beaulieu, M. (2009): Effect of season on the composition of bioactive polysaccharides from the brown seaweed Saccharina longicruris. - Phytochemistry 70: 1069-1075.

Rockstrom, J., Steffen, W., Noone, K., Persson, A., Chapin, F.S., Iii, Lambin, E., Lenton, T.M., Scheffer, M., Folke, C., Schellnhuber, H.J., Nykvist, B., De Wit, C.A., Hughes, T., Van Der Leeuw, S., Rodhe, H., Sorlin, S., Snyder, P.K., Costanza, R., Svedin, U., Falkenmark, M., Karlberg, L., Corell, R.W., Fabry, V.J., Hansen, J., Walker, B., Liverman, D., Richardson, K., Crutzen, P. \& Foley, J. (2009): Planetary Boundaries: Exploring the Safe Operating Space for Humanity. - Ecol. Soc. 14.

Rohde, S., Hiebenthal, C., Wahl, M., Karez, R. \& Bischof, K. (2008): Decreased depth distribution of Fucusvesiculosus (Phaeophyceae) in the Western Baltic: effects of light deficiency and epibionts on growth and photosynthesis. - Eur. J. Phycol. 43: $143-150$.

Ronnback, P., Kautsky, N., Pihl, L., Troell, M., Soerqvist, T. \& Wennhage, H. (2007): Ecosystem goods and services from Swedish coastal habitats: Identification, valuation, and implications of ecosystem shifts. - Ambio 36: 534-544.

Rosenberg, E. \& Falkovitz, L. (2004): The Vibrio shiloi / Oculina patagonia model system of coral bleaching. - Ann. Rev. Microbiol. 58: 143-159.

Russell, B.D., Thompson, J.-A., Falkenberg, L.J. \& Connell, S.D. (2009): Synergistic effects of climate change and local stressors: $\mathrm{CO} 2$ and nutrient-driven change in subtidal rocky habitats. Global Change Biol. 15: 2153-2162.

Saier, B. \& Chapman, A.S. (2004): Crusts of the alien bryozoan Membranipora membranacea can negatively impact spore output from native kelps (Laminaria longicruris). - Bot. Mar. 47: 265-271.

Sanderson, J.C., Ibbott, S. \& Foster, J. (2004): Restoration of string kelp (Macrocystis pyrifera) habitat on Tasmania's east and south coast. Report to National Heritage Trust. Seacare and Marine Environmental Systems, Hobart.

Saunders, M.I., Metaxas, A. \& Filgueira, R. (2010): Implications of warming temperatures for population outbreaks of a non-indigenous species (Membranipora membranacea, Bryozoa) in rocky subtidal ecosystems. - Limnol. Oceanogr. 55: 1627-1642.

Schaffelke, B., Peters, A.F. \& Reusch, T.B.H. (1996a): Factors influencing depth distribution of soft bottom inhabiting Laminaria saccharina (L.) Lamour. in Kiel Bay, Western Baltic. - Hydrobiologia 326-327: 117-123.

Schaffelke, B., Peters, A.F. \& Reusch, T.B.H. (1996b): Factors influencing depth distribution of soft bottom inhabiting Laminaria saccharina (L) Lamour in Kiel Bay, Western Baltic. - Hydrobiologia 327: 117-123.

Schall, J.J. (1992): Parasite-Mediated Competition in Anolis Lizards. - Oecologia 92: 58-64.

Schiel, D.R. \& Foster, M. (1992): Restoring kelp forests. - In: Thayer, G.W. (ed.), Restoring the Nation's marine environment, pp. 279342. Maryland Sea Grant College, Maryland, MD, USA.

Schiel, D.R. \& Foster, M.S. (2006): The population biology of large brown seaweeds: Ecological consequences of multiphase life 
histories in dynamic coastal environments. - Ann. Rev. Ecol. Evol. Syst. 37: 343-372.

Short, J., Kendrick, G.A., Falter, J. \& Mcculloch, M.T. (2014): Interactions between filamentous turf algae and coralline algae are modified under ocean acidification. - J. Exp. Mar. Biol. Ecol. 456: 70-77.

Steffen, W., Persson, A., Deutsch, L., Zalasiewicz, J., Williams, M., Richardson, K., Crumley, C., Crutzen, P., Folke, C., Gordon, L., Molina, M., Ramanathan, V., Rockstrom, J., Scheffer, M., Schellnhuber, H.J. \& Svedin, U. (2011): The Anthropocene: From Global Change to Planetary Stewardship. - Ambio 40: 739-761.

Steinhoff, F.S., Wiencke, C. \& Müller, R. (2008): Effects of ultraviolet radiation and temperature on the ultrastructure of zoospores of the brown macroalga Laminaria hyperborea. - Plant Biol. 10: 388-397.

Stekoll, M.S. \& Deysher, L. (1996): Recolonization and restoration of upper intertidal Fucus gardneri (Fucales, Phaeophyta) following the Exxon Valdez oil spill. - Hydrobiologia 327: 311-316.

Steneck, R.S., Graham, M.H., Bourque, B.J., Corbett, D., Erlandson, J.M., Estes, J.A. \& Tegner, M.J. (2002): Kelp forest ecosystems: biodiversity, stability, resilience and future. - Environ. Conserv. 29: 436-459.

Stout, M.J., Thaler, J.S. \& Thomma, B.P.H.J. (2006): Plantmediated interactions between pathogenic microorganisms and herbivorous arthropods - Ann. Rev. Entomol. 51: 663-689.

Sutherland, W.J., Aveling, R., Brooks, T.M., Clout, M., Dicks, L.V., Fellman, L., Fleishman, E., Gibbons, D.W., Keim, B., Lickorish, F., Monk, K.A., Mortimer, D., Peck, L.S., Pretty, J., Rockstrom, J., Rodriguez, J.P., Smith, R.K., Spaldin, M.D., Tonneijck, F.H. \& Watkinson, A.R. (2014): A horizon scan of global conservation issues for 2014. - Trends Ecol. Evol. 29: 15-22.

Tegner, M.J., Dayton, P.K., Edwards, P.B., Riser, K.L., Chadwick, D.B., Dean, T.A. \& Deysher, L. (1995): Effects of a large sewage spill on a kelp forest community: Catastrophe or disturbance? - Mar. Environ. Res. 40: 181-224.

Tegner, M.J., Dayton, P.K., Edwards, P.B. \& Riser, K.L. (1997): Large-scale, low-frequency oceanographic effects on kelp forest succession: a tale of two cohorts. - Mar. Ecol. Progr. Ser. 146: 117-134.

Terawaki, T., Hasegawa, H., Arai, S. \& Ohno, M. (2001): Management-free techniques for restoration of Eisenia and Ecklonia beds along the central Pacific coast of Japan. - J. Appl. Phycol. 13: 13-17.

Thiel, M. \& Gutow, L. (2004): The ecology of rafting in the marine environment-I - The floating substrata. - In: Gibson, R.N., Atkinson, R.J.A. \& Gordon, J.D.M. (eds.), Oceanography and Marine Biology: An Annual Review, Vol. 42, pp. 181-263.

Thompson, R., Wilson, B., Tobin, M., Hill, A. \& Hawkins, S. (1996): Biologically generated habitat provision and diversity of rocky shore organisms at a hierarchy of spatial scales. J. Exp. Mar. Biol. Ecol. 202: 73-84.

Torn, K., Krause-Jensen, D. \& Martin, G. (2006): Present and past depth distribution of bladderwrack (Fucus vesiculosus) in the Baltic Sea. - Aquat. Bot. 84: 53-62.

Ugarte, R.A., Critchley, A., Serdynska, A.R. \& Deveau, J.P. (2009): Changes in composition of rockweed (Ascophyllum nodosum) beds due to possible recent increase in sea temperature in Eastern Canada. - J. Appl. Phycol. 21: 591-598.
Underwood, A.J. (1992): Beyond Baci - the detection of environmental impacts on populations in the real, but variable, world. - J. Exp. Mar. Biol. Ecol. 161: 145-178.

Underwood, A.J. (1996): Detection, interpretation, prediction and management of environmental disturbances: Some roles for experimental marine ecology. - J. Exp. Mar. Biol. Ecol. 200: $1-27$.

Underwood, G.J.C., Thomas, J.D. \& Baker, J.H. (1992): An experimental investigation of interactions in snail-macrophyteepiphyte systems. - Oecologia 91: 587-595.

Vadas, R.L., Johnson, S. \& Norton, T.A. (1992): Recruitment and mortality of early postsettlement stages of benthic algae. British Phycol. J. 27: 331-351.

Vadas, R.L., Wright, W.A. \& Beal, B.F. (2004): Biomass and productivity of intertidal rockweeds (Ascophyllumnodosum LeJolis) in Cobscook Bay. - Northeastern Nat. 11: 123-142.

Vasquez, J.A. \& Vega, J.M.A. (1999): Effect of harvesting of brown seaweeds: a social, ecological and economical important resource. - World Aquaculture 30: 19-22.

Vega, J.M.A., Vasquez, J.A. \& Buschmann, A.H. (2005): Population biology of the subtidal kelps Macrocystis integrifolia and Lessonia trabeculata (Laminariales, Phaeophyceae) in an upwelling ecosystem of northern Chile: interannual variability and El Niño 1997-1998. - Rev. Chilena Hist. Nat. 78: 33-50.

Villalba, A., Reece, K.S., Ordás, M.C., Casas, S.M. \& Figueras, A. (2004): Perkinsosis in molluscs: A review. - Aquat. Living Res. 17: 411-432.

Vogt, H. \& Schramm, W. (1991): Conspicuous decline of Fucus in Kiel Bay (Western Baltic): What are the causes? - Mar. Ecol. Prog. Ser. 69: 189-194.

Wahl, M. \& Hay, M.E. (1995): Associational Resistance and Shared Doom - Effects of Epibiosis on Herbivory. - Oecologia 102: 329-340.

Wahl, M., Shahnaz, L., Dobretsov, S., Saha, M., Symanowski, F., David, K., Lachnit, T., Vasel, M. \& Weinberger, F. (2010): Ecology of antifouling resistance in the bladder wrack Fucus vesiculosus: patterns of microfouling and antimicrobial protection. - Mar. Ecol. Prog. Ser. 411: 33-U61.

Wahl, M., Jormalainen, V., Eriksson, B.K., Coyer, J.A., Molis, M., Schubert, H., Dethier, M., Karez, R., Kruse, I., Lenz, M., Pearson, G., Rohde, S., Wikstrom, S.A. \& Olsen, J.L. (2011): Stress ecology in Fucus: abiotic, biotic and genetic interactions. - In: Lesser, M. (ed.), Advances in Marine Biology , Vol. 59, pp. 37-105.

Watt, C.A. \& Scrosati, R.A. (2013): Bioengineer effects on understory species richness, diversity, and composition change along an environmental stress gradient: Experimental and mensurative evidence. - Estuar. Coast. Shelf Sci. 123: 10-18.

Weinberger, F., Buchholz, B., Karez, R. \& Wahl, M. (2008): The invasive red alga Gracilaria vermiculophylla in the Baltic Sea: adaptation to brackish water may compensate for light limitation. - Aquat. Biol. 3: 251-264.

Weinberger, F., Rohde, S., Oschmann, Y., Shahnaz, L., Dobretsov, S. \& Wahl, M. (2011): Effects of limitation stres and of disruptive stress on induced antigrazing defense in the bladder-wrack Fucus vesiculosus. - Mar. Ecol. Prog. Ser. 427: 83-94.

Wernberg, T., Russell, B.D., Thompson, M.S., Gurgel, F.D., Bradshaw, C.J.A., Poloczanska, E.S. \& Connell, S.D. (2011a): Seaweed Communities in Retreat from Ocean Warming. - Curr. Biol. 21: 1-5. doi:10.1016/j.cub.2011.09.028. 
Wernberg, T., Thompson, M.S., Tuya, F. \& Kendrick, G.A. (2011b): Biogenic habitat structure of seaweeds change along a latitudinal gradient in ocean temperature. - J. Exp. Mar. Biol. Ecol. 400: 264-271.

Wernberg, T., Smale, D.A., Tuya, F., Thomsen, M.S., Langlois, T.J., De Bettignies, T., Bennett, S. \& Rousseaux, C.S. (2012): An extreme climatic event alters marine ecosystem structure in a global biodiversity hotspot. - Nat. Climate Change 3: 78-82.

Wiencke, C., Roleda, M.Y., Gruber, A., Clayton, M.N. \& Bischof, K. (2006): Susceptibility of zoospores to UV radiation determines upper depth distribution limit of Arctic kelps: evidence through field experiments. - J. Ecol. 94: 455-463.
Wilson, J.B. (2011): The twelve theories of co-existence in plant communities: the doubtful, the important and the unexplored. J. Veg. Sci. 22: 184-195.

Young, T.P., Petersen, D.A. \& Clary, J.J. (2005): The ecology of restoration: historical links, emerging issues and unexplored realms. - Ecol. Lett. 8: 662-673.

Manuscript received: 1 September 2014

Accepted: 28 November 2014 